\title{
A Taxonomy of Multi-Industry Labour Force Skills
}

\author{
Davide Consoli \\ INGENIO, CSIC-UPV (Spain) \\ davide.consoli@ingenio.upv.es
}

Francesco Rentocchini

University of Southampton

f.rentocchini@soton.ac.uk

\begin{abstract}
This paper proposes an empirical study of the skill repertoires of 290 sectors in the United States over the period 2002-2011. We use information on employment structures and job content of occupations to flesh out structural characteristics of industry-specific knowhow. The exercise of mapping the skills structures embedded in the workforce yields a taxonomy that discloses novel nuances on the organization of industry. In so doing we also take an initial step towards the integration of labour and employment in the area of innovation studies.
\end{abstract}

Keywords: Industry dynamics; Skills; Taxonomy

JEL Code: C38; L0; J24; O33 


\section{Introduction}

This paper proposes an empirical analysis of the skill repertoires of the workforce in 290 industrial sectors of the United States (US) over the period 2002-2011. In so doing it addresses two questions:

(1) What are the skill configurations that characterize industries and sectors?

(2) Do particular skill configurations associate to specific industry types?

This study contributes various streams of scholarly research. First, it captures the correspondence between skill endowment and the organization of industry, an arguably underdeveloped theme in the area of innovation studies. In particular we identify specific categories of practical know-how that resonate with recent works on skills (Giuri et al, 2010; Neffke and Henning, 2013) and, also, explore empirical associations between these and industry characteristics. Another contribution of the paper is the articulation of important nuances on cross-industry differences that goes beyond macro-level evidence (e.g. Howell and Wolff, 1992; Autor et al, 2003). Last but not least, the classification of industry groups on the basis of the skill content allows us to propose a new taxonomy that adds to previous literature, in particular Pavitt (1984) and Castellacci (2008). In the last part of the paper we also observe that the distinctively dynamic character of employment and skills, and the complicated role of technology in them, bode well for greater engagement on these themes on the part innovation scholars.

The paper is structured as follows. Section 2 prepares the ground by outlining the theoretical backdrop and our proposed operazionalisation of the main concepts at stake. The empirical analysis of Section 3 illustrates important nuances of skill structures, and explores basic empirical regularities within industry types. Section 4 explores commonalities and differences with other taxonomic exercises in the innovation literature. The last section concludes and summarizes.

\section{Background}

The area of innovation studies is the field of research that has arguably explored in greater detail the relation between knowledge, industry evolution and competitiveness. A full review is beyond the scope of this paper but suffice it to say that the debate is often couched in terms of the ontology of technological knowledge, or the articulation of processes by which knowledge is organized and diffused, or the assessment of the contexts in which different 
kinds of knowledge are put to use (see Rosenberg, 1976; Cowan et al, 2000; Metcalfe, 2001; Foray, 2004; Antonelli, 2006). A wealth of empirical evidence indicates that heterogeneity is the trademark of knowledge-driven transformation at various levels of aggregation including firms (Bottazzi, et al 2002; Shrolec and Verspagen, 2012), industries and sectors (Pavitt, 1984; Mowery and Nelson, 1999; Malerba, 2002), clusters (Jensen et al, 2007) as well as regional (Cooke et al, 1997; Asheim and Cohenen, 2005) and national systems of innovation (Nelson, 1993; Carlsson et al, 2002). The causes of this diversity cannot be reduced to a single factor but, rather, are ascribed to complementary transformations in the knowledge base, the networks of actors and institutional infrastructures (Amable, 2003; Nelson, 1994; Malerba, 2005). Central to this view is the notion that beneath industry dynamics are the cyclical decline of obsolete activities and the emergence of new ones that disrupt the extant order and induce a transformation in the "way of doing things". These adjustments are necessary to either restore or create ex novo appropriate conditions for productive specialization (Nelson, 1994; Metcalfe and Ramlogan, 2005).

The present paper seeks to contribute to the area of innovation studies by focussing on employment, a crucial driver of industry evolution. To be sure, the role of the labour input in the organization of industry is a common, if understated, thread across various areas of scholarly research. The management literature focuses on strategic aspects related to the coordination of know-how and attitudes across employers (Cohen and Levinthal, 1989; Kogut and Zander, 1992). Scholars in business economics ascribe differences in firm performance to differential abilities within the workforce in creating and using knowledge (Geroski et al., 1993; Henderson and Cockburn, 1996; Johnson et al, 1996). More recent empirical work puts emphasis on the mutual influence between employees' skills and forms of innovation (see e.g. Leiponen, 2005; Freel, 2005; Lavoie and Therrien, 2005). Last but not least, empirical studies in economics explore the impact of Information and Communication Technologies on the content, the structure and the dynamics of employment with special emphasis on the sources of wage inequality (Galor and Moav, 2000; Autor et al, 2003; Goldin and Katz, 2008).

A point in common across all these works is the scarce consideration towards the sheer diversity across forms of knowledge, and of the consequences on the organization of industry. This paper brings these ideas within the remit of innovation studies by looking at the skills that are required to perform job tasks. In the view proposed here sectors are bundles of tasks whose execution entails the generation and/or application of specific knowledge 
(Richardson, 1972; Nelson and Winter, 1982). ${ }^{1}$ In turn occupations are industry-specific pathways for matching skills with institutionally agreed tasks and skills are the individual abilities that determine the proficiency in carrying out these job activities (Autor et al, 2003; Levy and Murnane, 2004). In aggregate, the composition of the workforce at industry level reflects the knowledge mix that is relevant at any particular point in time.

Following an established tradition within innovation studies we operationalize the analysis of industry evolution by means of a classificatory exercise of the knowledge base. The first effort in this direction was Pavitt's (1984) renowned study of the technological characteristics of UK firms which became the basis for a sectoral taxonomy. This has been and continues to be a point of reference for scholars, policy makers as well as for statistical offices designing large-scale data collection programs (Archibugi, 2001; Peneder, 2003). On a conceptual level the use of taxonomic exercises has inspired a great deal of research on various industry characteristics such as technological opportunities, knowledge cumulativeness, knowledge bases, appropriability conditions, R\&D intensity and skills (see e.g. Los and Verspagen, 2004; Breschi et al., 2000; Van Dijk, 2000; Malerba and Montobbio, 2003; Reichstein and Salter, 2006; Krafft et al, 2011). ${ }^{2}$ At the same time greater availability of sector-specific data (such as, for example, the European Community Innovation Survey) has expanded the intellectual scope and the policy remit of classification exercises. This is especially true in the area of studies on service sectors (e.g. Evangelista et al., 1997; Miozzo and Soete, 2001; Leiponen and Drejer, 2007; Castellacci, 2007) where greater understanding of the dynamics of technological paradigms has stimulated both the toning down of the arguably blunt separation between manufacturing and services and, at the same time, a stronger appreciation of the growing diversity that exists across these sectors (Castellacci, 2008; Peneder, 2010; Consoli and Elche, 2010; 2013).

The remainder of the paper puts these concepts to use and proposes a taxonomic exercise based on a hitherto overlooked dimension of analysis, namely the knowledge base of occupations within industrial sectors.

\footnotetext{
${ }^{1}$ This is not to say that the issue has been completely neglected: Freeman et al (1982), Vivarelli (1995), Edquist et al (2001), and Petit and Soete (2002) are important contributions on the appreciation of the mutual influence of technology, especially Information Technology, and labour. Our claim is, rather, that there have been no attempts to build on that empirical evidence to the effect of integrating the dynamics of employment in a broad theoretical framework such as those of Nelson and Winter (1982) or Metcalfe et al (2006).

${ }^{2}$ For critical views on the use and misuses of sectoral taxonomies see Archibugi (2001) and Shrolec and Verspagen (2012).
} 


\section{Data and Analysis}

This section presents an empirical analysis of 290 industrial sectors in the United States over the period 2002-2011 with a view to uncover structural and dynamic aspects of industry evolution. Building on the conceptual background laid out above, we propose a taxonomy of industry based on the intuition that the knowledge base of a sector is a portfolio of skill combinations, whereby the co-occurrence of two particular skills in one profession is interpreted as a measure of the joint utilization of those types of know-how. Clearly mastering diverse skills determines workers' ability to meet successfully job requirements, but successful adaptation to new job tasks requires also collaboration across occupations and some degree of teamwork. This is why we prefer to focus on the industry level, since the fate of any individual occupation may conceal broader alterations in the structure of production due to modifications in the job content, in the creation of new occupations, or both, (Autor et al, 2003) that would otherwise be unnoticed. Being channelled through the instituted process of employment all these changes are easily detectable by looking at the composition of the labour force. The remainder of this section presents the dataset and the empirical analysis.

\section{1 - Data description}

The key objective of this study is the construction of an industry taxonomy based on the analysis of skill repertoires. The main source is the Occupational Information Network (O*NET) electronic database of the U.S. Department of Labour (DOL) containing specific information on the characteristics of more than 1000 occupations. For the purpose of the present paper we use information concerning the physical and cognitive abilities that are required from workers. This is generated by means of a survey in which occupational analysts, job incumbents and occupational experts are asked to assign a score to 35 types of skills (see Appendix A) on the basis of their importance for performing the occupation. Skills encompass various categories: “basic” (e.g. reading, writing and listening), “processing” abilities (e.g. gathering and organizing information), “social” (e.g. interaction with others) and "technical" (e.g. maintenance and repairing) abilities. ${ }^{3}$ Each of these items is assigned a score by $\mathrm{O}^{*} \mathrm{NET}$ survey respondents, and is subsequently matched with other data using the Standard Occupational Classification (SOC) code.

The database used here was built relying on different sources. First, we retrieved from Bureau of Labor Services (BLS) data for employment and the average number of years in

\footnotetext{
${ }^{3}$ For further information about O*NET see National Research Council (2010).
} 
excess of High-School (Standard Vocational Preparation) on a unique combination of 22 two-digit SOC occupations and 290 four-digit NAICS US industrial sectors for the period 2002-2011. This information was subsequently matched with the corresponding occupational information of $\mathrm{O}^{*} \mathrm{NET}$, thus generating a vector of skill scores for each of the 22 two-digit SOC occupations. We also gathered information at the four-digit NAICS level on labour productivity (Source: US Bureau of Labor Statistics), on the number of firms per sector (Source: Business Dynamics Statistics, US Census), on Capital Expenditures for Structures and Equipment (Source: US Census).

Following the preamble above, we submit that changes in the repertoire of skills reflect the evolution of industry needs and that the associated change in the knowledge base is likely to engender, or to reinforce, systematic cross-industry heterogeneity. To operationalize these ideas, we aggregate occupation-specific information on skills by industry using relative scores, that is, weighted measures of skill intensity (see Oldenski, 2012). First, we multiply the skill score at the unique 2-digit SOC and 4-digit NAICS by the number of years in excess of High-School. Subsequently we normalize the resulting values to fix a range between 0 and 100 and compute the following skill measure:

$$
\text { Skillint }_{s, \text { ind }}=\sum_{o c c} \text { EmpShare }_{o c c, \text { ind }} * \text { NormSkill }_{s, o c c, \text { ind }}
$$

where EmpShare occ,ind $_{\text {is }}$ the relative importance in terms of employment of occupation occ in

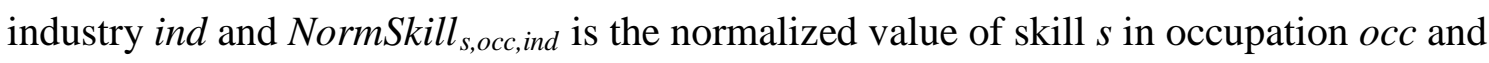
industry ind. Summing over occupations in each industry yields an input intensity measure of each skill $s$ in each industry ind (SkillInt $\left.t_{s, i n d}\right)$. After this transformation we are left with 290 industry-specific intensity measures for each of the 35 skill types for each of the ten years under analysis.

\section{2 - Constructing the taxonomy: skills and sectors}

The original data contains 35 skill variables. Recall that we are not interested in their absolute values but, rather, in the way skills combine within industry-specific occupational structures. Moreover, the raw scores of skill intensity are highly correlated with each other due to high complementarity across skill endowments at industry level. To meet the former goal and to overcome the latter limitation, we reduce the set of skill indicators to a smaller number of 
non-overlapping dimensions by means of a factor model (see e.g Castellacci and Archibugi, 2008). Table 1 presents a compact view of the skill constructs extracted from the 35 indicators of skill intensity for the period 2002-2011. ${ }^{4}$ Note that different methods of factor extraction - principal components, iterated principal factors and maximum likelihood - yield consistent results. Altogether the factors explain a large percentage of the variance. ${ }^{5}$

\section{TABLE ONE ABOUT HERE}

Previous literature assists the interpretation of these two constructs on the basis of functional specificities (Autor et al, 2003; Wolff, 2006). First of all, we note that our constructs fit squarely with Herbert Simon's (1969) notion of problem-solving as the combinatorial outcome of different types of knowledge. Indeed, the first factor includes items that involve the use of cognitive abilities in non-routine circumstances, like interpersonal interaction or abstract thinking, and is labelled Interactive \& Abstract Skills. The second construct, Technical \& Analytical Skills, contains a broad range of cognitive and manual abilities employed for routine tasks such as managing or recombining existing information, or when operating specialized technical equipment. The cognitive and manual abilities within this second construct are normally employed for highly routinized tasks that are more prone to automation like calculation or information processing (see Autor et al, 2003).

Following on the above, sectors are grouped together on the basis of the skill distributions embedded in their occupational structures. In particular we apply clustering techniques to factors scores ${ }^{6}$ by means of regression methods (Thomson, 1951) and use them as inputs in the clustering algorithm. ${ }^{7}$ This exercise yields three clusters (see Appendix B for a full summary). The first, Complex Production and Distribution, includes the majority of Hi- and Medium- Tech Manufacturing, and some knowledge intensive services. ${ }^{8}$ The core of this

\footnotetext{
${ }^{4}$ To select the number of factors to be retained we employ a combination of three common rules of thumb suggested in the literature - see Gorsuch (1983): (i) we retain only those factors with an eigenvalue larger than one (also known as Guttman-Kaiser rule); (ii) we keep the factors which, in total, account for about more than $80 \%$ of the variance and (iii) we retain all factors before the breaking point in the scree-plot. In all these cases, our results consistently point to two factors to be retained.

${ }^{5}$ The two factors are robust to alternative estimations for individual years and for various blocks of multiple years. Results are in line with those presented above and are available from the authors upon request.

${ }^{6}$ Factor scores have been standardized to range between -1 and 1 . Thus, a positive (negative) value of a factor score should be interpreted as an above-(below-) average value.

${ }^{7}$ We use different hierarchical clustering methods (average linkage, centroid linkage and Ward's linkage) based on the Calinski-Harabasz pseudo F-statistic and the Duda-Hart index stopping rules for selecting the optimal number of clusters. Finally we check the robustness of the results with a Partition-clustering method.

8 The labels Hi-, Medium- and Low-Tech for Manufacturing, and High- and Low-Knowledge-Intensity Services have been assigned on the basis of the NACE-based Eurostat classification, and subsequently converted to the
} 
cluster, calculated as the 90th percentile by mean skill intensity, includes industries like Satellite Telecommunications (NAICS: 5174); Software Publishers (5112); Computer Systems Design Services (5415); Manufacturing of Computer and Peripheral Equipment (3341); Data Processing and Related Services (5182); Architectural, Engineering, and Related Services (5413); Communications Equipment Manufacturing (3342). In the second cluster, labelled Basic Production and Distribution, are the bulk of Low-Tech Manufacturing industries and Service activities with low knowledge intensity, mostly commercial activities complementary to the former. At its core are Iron and Steel Mills Manufacturing; Commercial Refrigeration Equipment Manufacturing; Tobacco Manufacturing; Utility System Construction; Coal Mining; Vending Machine Operators; Automotive Repair and Maintenance. The last cluster, People Services, contains service activities characterized by direct interaction with customers such as Legal Services; Securities and Commodity Exchanges; Instruction Services; Insurance and Employee Benefit Funds; Central Bank; Internet Publishing and Broadcasting; Investment Pools and Funds.

\section{3 - The taxonomy at work: an illustrative analysis}

Let us explore more in detail the characteristics of the constructs at hand. Figure 1 offers a compact view of the distribution of Industry-Clusters in the know-how space defined by both the Skill-Factors. Each point in the scatterplot is a 4-digit NAICS industry arranged by their relative Skill-Factor intensity and labelled by shapes depending on the cluster they belong to. For analytical purposes, we find it convenient to further distinguish observations that are either manufacturing or to service activities. The diagram clearly shows that industries in Complex Production and Distribution (Cluster 1) exhibit a higher than average value of both Interactive \& Abstract Skills and Technical \& Analytical Skills. This is not surprising since in this construct are activities like high- and medium- tech manufacturing or KIBS, thus requiring not only a high level of knowledge intensity but also a good degree of complementarity between different types of know-how, therein including analytical skills, creative thinking as well as interactive skills. In the language of Herbert Simon (1969: 87) these are ‘semantically-rich’ domains, that is, activities whose task structures are characterized by strong specificity and require high levels of cognitive responsiveness to construct ad-hoc mental frameworks and performance criteria. Industries in the second cluster, Basic Production and Distribution, exhibit a lower than average value of Interactive

NAICS system. See http://epp.eurostat.ec.europa.eu/statistics_explained/index.php/High-tech_statistics. For a critical view of this classification see Godin (2004). 
\& Abstract Skills. This resonates with the population items that populate the cluster, mostly production of consumer durables, processing or raw materials or trade and activities that, in general, require more manual and technical abilities than abstract thinking. The defining feature of Basic Production and Distribution is that it encompasses 'non semantically-rich domains' strongly biased towards standardized tasks. In this type of domains the repertoire of problem-solving options is known ex-ante with a finer degree of precision, and replication of existing routines through non-cognitive skills suffices (Simon, 1969; Autor et al, 2003). Finally, People Services mainly comprise Knowledge Intensive Services such as teaching, social and community services but also financial intermediation, and indeed they score rather high in Interactive \& Abstract Skills but not in Technical \& Analytical Skills. This exercise also illustrates the ubiquity of service activities as well as their functional specificities depending on whether they exhibit complementarity with manufacturing, as in the case of the first two clusters, or they rather stand in a category of their own like in the People Services construct. This result resonates with recent analyses of sectoral specificities (see Castellacci, 2008; Peneder, 2007; Consoli and Elche, 2010).

\section{FIGURE ONE ABOUT HERE}

To gain a clearer characterization of these constructs we check for statistical correspondences between Skill-Factors and Sector-Clusters. This is done by regressing the likelihood of belonging to a particular cluster against the skill constructs and a set of other industry characteristics (see Section 3.1) such as capital expenditure in infrastructures, capital expenditure in office equipment, labour productivity (measured as average hourly wage ${ }^{9}$ ) and number of firms (in thousands). We also include a set of dichotomous variables taking value 1 when the industry belongs to one of the industrial categories Hi- and Low-Tech Manufacturing, High- and Low-Knowledge Intensive Services (see Footnote 10). We believe that this exercise contributes to provide a characterisation of our clusters across relevant dimensions in a descriptive flavour.

The results (Table 2) corroborate preliminary insights obtained by the inspection of Figure 1 and indicate that the probability of belonging to the Complex Production and Distribution cluster is positively and significantly associated with both Interactive \& Abstract Skills and Technical \& Analytical Skills. This is to say that occupations within these industries employ a broad set of skills or, put otherwise, that their task content embraces a wide spectrum of

\footnotetext{
${ }^{9}$ As for raw measures of skills wage data are available at the unique two digit SOC and four digit NAICS level. We aggregate hourly wage at the industry level by weighting for employment shares.
} 
cognitive and non-cognitive activities. Conversely industries in the Basic Production and Distribution cluster have a negative association with Interactive \& Abstract Skills, meaning that the values of that particular skill type are significantly below average compared to the other clusters. Finally, sectors within the People Services cluster have a significant and positive association with Interactive \& Abstract Skills and a negative one with Technical \& Analytical Skills.

For what concerns the other dimensions, Complex Production and Distribution exhibit a positive and significant association with capital expenditure in office machinery. This is expected, and in line with the literature that emphasises the complementarity between ICTs and cognitive skills (Autor et al, 2003; Levy and Murnarne, 2004). On the other hand the negative sign of the coefficient for capital expenditure in infrastructures is somewhat expected too, considering that it signals that this type of resource commitment has relatively lower importance in this kind of knowledge intensive activities. At the same time we use dummies to check whether the probability of belonging to the clusters varies across industry ecologies. In the case of Cluster 1 we observe some degree of diversity since the coefficients are positive and significant for all types, relatively more for Hi-Tech Manufacturing. This configuration stands in contrast with that of the Basic Production and Distribution cluster whereby the coefficients for capital expenditure suggest that investments in infrastructure play a stronger role. The coefficient for number of firms is negative and non-significant in this construct and, also, no industry type exhibits positive and/or significant probability to fall in this group. The composition of People Services on the other hand is rather clear due to the prominent role of interactive and abstract skills (as seen in Figure 1) which resonates with the positive and significant coefficient of H-KIS. Lastly, the test equality of coefficients indicates that the difference between the coefficients of Interactive \& Abstract Skills in both Complex Production and Distribution and in People Services is not significantly different from zero. This suggests that the skill factor is similarly important in both constructs. Conversely, the two clusters differ for what concerns the effect of Technical \& Analytical Skills which are significantly different from Interactive \& Abstract Skills in Complex Production and Distribution cluster. ${ }^{10}$

\footnotetext{
${ }^{10}$ The Breusch-Pagan test, significant at 1\% level, indicates that the residuals of the three clusters are not independent and justifies the use of multivariate regression. It is worth stressing that in this method, different from multiple regression, dependent variables are jointly regressed on the same independent variables. The joint estimators of multivariate regression are built on the between-equation co-variances, and allow testing for relevant factors across equations. This way we can learn about their relative importance in each cluster.
} 


\section{TABLE TWO ABOUT HERE}

The analysis so far has been concerned with uncovering structural aspects of the cognitive content of industries. As anticipated in the conceptual framework outlined of Section 2, the salient mark of industry evolution is the emergence of significant and persistent crossindustry differences. It seems therefore relevant to analyse the dynamic behaviour of both skill-factors and of industry clusters change over time. To this end we first check whether skill-factor intensity is homogeneous across sectors. The kernel density distributions in Figure 2 offer two clear hints. ${ }^{11}$ First, the right-skewed shapes suggest high concentration, or uneven distribution across sectors, more so for of Interactive \& Abstract Skills (Factor 1) compared to Technical \& Handling Skills (Factor 2). As for the longitudinal behaviour, the kernel curves for years 2002, 2006 and 2011 indicate significantly different patterns of change. The upward-left shift between 2002 and 2006 of the distribution of Factor 1 indicates that the majority of industries gather around low and medium-high levels of skill-factor intensity. In the second part of the decade the trend is reversed and skill concentration in 2011 is close to the levels of 2002, but still highly skewed. The case of Factor 2 is quite different in that the initial kernel density curve is bi-modal, and then it progressively becomes bell-shaped, though not normally distributed. ${ }^{12}$

\section{FIGURE TWO ABOUT HERE}

These patterns resonate with the view that the distribution of 'soft' skills, such within Factor 1 , is uneven across sectors because they are heavily context-dependent and, thus, harder to standardize (Bartel and Lichtenberg, 1987; Autor et al, 2003; Vona and Consoli, 2015). The broad message that emerges from this graphical analysis is that there is high variation in the distribution of skill intensity across industries, and that path-dependence in the organization of labour routines tends to reinforce the bias (David, 2000; Amable, 2003).

\section{Discussion}

The empirical analysis of the preceding section has provided several insights concerning the organization of industry through the lenses of the skills embedded in the workforce. To recap, we synthesised the distributions of relative skill intensity in two constructs that capture salient characteristics of the knowledge content of occupations: Interactive \& Abstract Skills,

\footnotetext{
${ }^{11}$ Here we select the industries whose skill intensity lies below the 90h percentile to control for outliers at the far extremes of the distributions.

12 The coefficients of the Kolgorov-Smirnov test confirm the non-normal distributions: for Factor 1, 2002: 0.19***; 2006: 0.16***; 2011: 0.16***. For Factor 2: 2002: 0.17***; 2006: 0.09**; 2011: 0.1***
} 
normally associated to non-routine tasks, and Technical \& Analytical skills that are mostly involved in carrying out routine activities. We subsequently fed back these results in the grid of 290 industrial sectors and obtained three clusters that capture distinctive patterns of knowledge organization across industrial sectors. Let us now reflect on these results and offer a broader view of the contribution of the present study.

To do so we propose a heuristic comparison between our industry taxonomy and other similar empirical exercises in the literature. Taxonomies are often elaborated with the intent of offering a compact view of multi-dimensional constructs, like industry, while not losing sight of the underlying richness. The effort of undertaking yet another taxonomic classification is partly motivated by the curiosity of testing the generalizability of existing constructs when new information, such as the skill content of occupations, becomes available. Could have we used existing taxonomies for the analysis of industry knowledge bases? To what extent our constructs add to previous work? We tackle these questions by checking how much previous taxonomies capture the skill content of industries. ${ }^{13}$

The selection of candidate studies for such a task is not easy considering the sheer breadth of options available (see Peneder, 2003 for a review). After a thorough revision of the literature we picked two key antecedents for the sake of comparison. Our first choice is Pavitt's renowned taxonomy, a point of reference for virtually all industry classifications. This was built through a detailed assessment of about 2000 inventions and firms in the UK between 1945 and 1979 using size, innovation patterns and sources of innovation as organizing criteria. The resulting constructs are Scale-Intensive (SI), Supplier-Dominated (SD), ScienceBased (SB) and Specialised Supplier (SS). A well-known criticism is the scarce consideration to service activities in this taxonomy, especially in view of their fast growth in both size and importance across most advanced economies. To accommodate this insight we use Miozzo and Soete's (2001) revision of the Pavitt taxonomy and include two categories of service activities, namely Personal Services (PS), which includes KIBS as well as intermediation activities, and Non-Personal Services (NPS), which encompasses all other service activities (Castaldi, 2009). Our second choice is the taxonomy by Castellacci (2008) built using Community Innovation Survey (CIS) data with the goal of offering an integrated classification of manufacturing and service sectors. The sorting criteria are two: the function that each industry plays in the broader eco-system through the supply or the demand of goods

\footnotetext{
${ }^{13}$ We are indebted to an anonymous referee for drawing our attention to this issue and for suggesting this comparative exercise.
} 
and services, and the level of technological capabilities of innovative firms within a particular group of industries. This taxonomy contains four meta-categories: (i) Advanced Knowledge Providers (AKP) which include KIBS but also specialized manufacturing such as machinery and equipment, medical and optical instruments; (ii) Mass production Goods (MPG) featuring science-based manufacturing (i.e. chemicals, computers), electrical machinery but also scale-intensive manufacturing (i.e. rubber and plastic products; basic metals; motor vehicles); (iii) Supporting Infrastructure Services (SIS) encompassing network infrastructure services (i.e. Post and telecommunications), financial intermediation as well as wholesale trade and transport activities; and (iv) Personal Goods and Services (PGS) which includes supplier-dominated goods (i.e. food and beverages; textiles; leather) together with supplierdominated services such as Sales, maintenance and repair of motor vehicles; retail trade and repair of personal and household goods; hotels and restaurants. ${ }^{14}$

For the purpose of a comparative analysis we assigned each of the 290 4-digit NAICS industries to a unique class within the other taxonomies. In all cases the industrial classification of reference is NACE rev. 2. Accordingly we built a crosswalk between our 290 4-digit NAICS and 2-digit NACE rev.2 sectors to the effect of matching industries in the two sets. ${ }^{15}$ After this step we are left with 285 4-digit NAICS. ${ }^{16}$ Appendix B provides the result from the crosswalk where each 4-digit NAICS industry has been assigned to a 2-digit NACE rev. 2 code and then, following the relevant contribution (Pavitt 1984; Miozzo and Soete, 2001; Castellacci, 2008) to the respective industrial class. As a result, the 285 industries in our dataset can be classified according to the taxonomies of Pavitt-Miozzo-Soete (PMS) and Castellacci (FC). Subsequently we proceeded in three steps.

First, we cross-tabulated industry co-occurrences between our taxonomy and the others to detect overlaps with a cut-off value of $40 \% .{ }^{17}$ The logic is as follows. A high overlap suggests that the distribution of industries in our Cluster constructs coincides with that of other taxonomies. Arguably a systematic overlap indicates that our taxonomy may be redundant because it does not add much to previous work. When a high overlap between

\footnotetext{
${ }^{14}$ Heuristic comparisons have been tried with other taxonomies in the literature but for the sake of parsimony we restrained to the two above. Further trials are available by the authors upon request.

${ }^{15}$ Our starting point was the concordance table provided by CENSUS and available at: http://www.census.gov/eos/www/naics/concordances/concordances.html.

${ }^{16}$ We were unable to allocate five 4-digit NAICS to 2-digit NACE rev.2. These are: 4821 (Rail Transportation), 5251 (Insurance and Employee Benefit Funds), 9991 (Federal Executive Branch and United States Postal Service), 9992 (State Government) and 9993 (Local Government).

${ }^{17}$ We set the cut-off value at $40 \%$ for ease of exposition. Results hold in terms of the robustness and differentiation irrespective of the cut-off value. Results are available from the authors upon request.
} 
clusters of different taxonomies was detected, we moved to the next step, the actual comparison of the identified groups by means of multivariate regression similar to the previous section. The goal is to assess the relationship between different types of skill intensities and the probability of being part of a group in a different taxonomy compared to our classification conditional on the set of industry characteristics. Clearly, one of our clusters and a cluster from a different taxonomy can share a number of industries but can also contain industries extremely different in the remaining group. By regressing the likelihood of belonging to a particular group against a number of characteristics we can appreciate the extent of the similarity. The last step of our procedure consists in comparing the skill coefficients across models and testing statistically the contribution of the skill factors to the cluster. Specifically, for each skill factor construct we compute one parameter vector and simultaneous (co)variance matrix of the sandwich/robust type and then we test whether their difference is significantly different from zero. Doing so allows us to check whether other classifications capture the relative importance of skill repertoires across industries. We now present these comparisons and comment them in the last subsection.

\section{1 - Comparison with Pavitt-Miozzo-Soete taxonomy}

Table 3a reports the cross-tabulation between our clusters and those of Pavitt-Miozzo-Soete (PMS): industry co-occurrences are expressed by percentages. The Pearson $\chi^{2}$ test of independence (statistically different from zero) suggests the existence of an association between the two groups. As shown in the Table our Cluster 1, Complex Production and Distribution, is spread across most PMS groups with no two constructs from either classifications showing strong overlap (highest overlap 29\% with Scale Intensive, SI). This suggests that the two taxonomies capture different things. At the same time we detect significant overlaps between two sets of groups: Basic Production and Distribution (cluster 2) and Non-People Services in NPS (48\% co-occurrences); and People Services and Personal Services $46 \%$. Coherent with the prelude to this analysis, we concentrate on the comparison of these two subsets of industries.

Let us check whether these associations are merely quantitative or whether they are due to the actual composition of the constructs. The multivariate regression in Table 3b indicates that the overlap between our People Services and PMS’ Personal Services reflects some similarity. Indeed, the Breusch-Pagan test is highly significant, thus suggesting that the 
residuals of the two models are dependent. ${ }^{18}$ A closer look at the coefficients of the first two models in Table 3b supports the intuition that the similarity between the two constructs is driven by industry ecology, and therefore by the industry types (i.e. H-KIS, H-TECH, et cetera), more than anything else. The coefficient of the skill factors in both groups share the same sign but not the same level of significance. On the other hand, Basic Production and Distribution shows no significant association with PMS' Non-Personal Services. The Breusch-Pagan test does not reject independence of the residuals, and a comparison of the coefficients does not suggest any similarity. Last but not least, the tests of equality between coefficients at the bottom of Table 3b offer further insight on the extent to which the constructs are qualitatively similar. For what concerns Interactive and Abstract Skills we find that the coefficients are significantly different in both comparisons. Conversely, the coefficients for Technical and Analytical Skills are significantly different only in the first comparison, People Services vs NPS.

\section{TABLES 3a and 3b ABOUT HERE}

\section{2 - Comparison with Castellacci’s taxonomy}

Table 4a shows the cross-tabulation of our clusters with the categories Castellacci (2008). Again the rejection of the Pearson $\chi^{2}$ test of independence suggests the possibility of some quantitative association between the groups in the two taxonomies. Indeed we observe high co-occurrences between Basic Production and Distribution and Personal Goods and Services (PGS) (55\%), and between People Services and again PGS (56\%). Like before, we use multivariate regression to compare the two groups (Table $4 \mathrm{~b}$ ).

The first two columns show that the coefficients of our cluster 1, Basic Production and Distribution, and of Castellacci's PGS are mostly at variance for what concerns both significance levels and the signs. This is confirmed by the non-significant value of the Breusch-Pagan test. On the whole this resonates with a closer look at the nature of the two constructs: our cluster is populated mostly by low-tech manufacturing and trade activities while Castellacci's includes KIBS and other such services. Thus, the similarity between the two is only apparent. Moving to the other comparison, we detect a somewhat stronger correspondence between People Services and PGS, especially for what concerns the

\footnotetext{
${ }^{18}$ Although Breusch-Pagan test was originally developed to test for heteroschedasticity in a linear regression model, it seemingly applies to test independence among equations in multivariate regression models. In our case, we calculate the F-test in a regression containing all the estimated squared residuals from the different regressions of the multivariate model. If this test confirms that all residuals are jointly significant then the null hypothesis of independence among equations in the multivariate model can be rejected.
} 
coefficient and the significance levels of the associated skill factors. But again, the BreuschPagan test indicates that the residuals are independent. This is further corroborated by the tests reported at the bottom of Table $4 \mathrm{~b}$ showing that when comparing Basic Production Distribution and Castellacci's PGS, the coefficients for Interactive and Abstract Skills and Technical and Analytical Skills are significantly different between the two taxonomies. On the other hand the Breusch-Pagan test reveals significant similarity in Technical and Analytical Skills between People Service and Castellacci's PGS indicates. Put otherwise, the PGS group properly captures the skill content of this group of industries.

\section{TABLES 4a and 4b ABOUT HERE}

\section{3 - Summing up}

The key message stemming from this analysis is that industries differ in the variety of capabilities they employ. These differences do not depend solely on which skills are used but also on how skills combine with each other. This is why we argue that labour is a useful empirical dimension: employment structures are akin to coordinating devices for ensuring coherence between what is required from the workforce and the pool of capabilities that are available. The heuristic comparison between our taxonomy and other comparable classificatory exercises indicates that the skill-based analysis captures an aspect of industry organization that previous works do not. Indeed when the direct comparison between candidate groups suggests broad similarities, there is a systematic variance in the relative intensity of industry-specific skills. In formal terms, this means that the industry-cluster construct is due to a 'within industry' effect, viz. intensity of use of a particular skill, and a 'between industry' effect reflecting the comparative cognitive specialization of some industries compared to others.

The first comparison suggests that our taxonomy captures patterns of combinations of knowhow that fall outside of the remit of Pavitt, Miozzo and Soete. We ascribe this to the absence in our constructs of the manufacturing-services dualism that was rather common to early taxonomic exercises. Such a division is partly grounded in historical reasons given that the interpenetration between increasingly complex products and ever-more refined services has gained consensus among scholars only over the last fifteen years (see e.g. Miles, 2005). The confirmation of this is that KIBS, once considered a monolithic block of high-level services, emerge from our analysis as a very diverse group encompassing professional activities that rely on specialist technical know-how, for example Engineering or Computer System Design, 
but also highly interpersonal or even creative services, such as legal assistance and advertisement. And, indeed, different types of KIBS belong to different cluster constructs in our taxonomy. ${ }^{19}$ This lends support to the idea that cross-sectoral differences are not so much due to some activities belonging to 'high-' or 'low-' categories - regardless of whether the prefix applies to technology or knowledge - but rather on how work activities are organized and on the particular type of know-how they use.

Turning to the other comparison, the similarity between Castellacci’s Personal Goods and Services group and our People Services cluster is not surprising. A closer look at these constructs reveals that, beyond mere industry matching, the know-how content is similar, prominently interpersonal and communication skills as well as cognitive ability to think creatively. What is most striking however, and this applies to the comparison with PMS' taxonomy, is the lack of a match with our Complex Production and Distribution cluster. It is worth reminding that this is a distinctive group of industries exhibiting a strong and positive association with both Interactive and Abstract Skills and Technical and Analytical Skills factors. We interpret this cluster as a reflection of significant transformations occurred in the US economy over the last fifteen years due to the maturing of the technological base and the concurrent expansion of international trade. For what concerns the former, the literature has shown convincingly that the first wave of computer diffusion exerted a positive selection effect on high-skill professionals - mostly jobs entailing intensive use of abstract skills - and a negative effect on routine-intensive occupations - mostly jobs whose core tasks (i.e. processing information or assembling) were displaced by computer capital (Autor et al, 2003). As this technology reached maturity, at least in the early domains of application such as office and industrial machinery, the attendant specialist know-how has been codified and widely diffused and this has progressively reduced the initial comparative advantage of highskill workers (Vona and Consoli, 2015). At the same time the pressure of unprecedented growth in international trade on the US and other advanced economies has accelerated the fragmentation of supply chains and the switch to high-quality products relying intensively on a broad range of Non-Routine skills (Baldwin, 2011; Consoli et al, 2014). These developments have not undermined the importance of technical know-how but, rather, changed the way in which this is strategically used, notably in conjunction with interpersonal skills. Put another way, the emergence of a highly specialized cluster that brings together Hi-

\footnotetext{
${ }^{19}$ Though this would have not surprised an economist of past generations like Solomon Fabricant who made a compelling case about the heterogeneity of services in a rather old manuscript (Fabricant, 1972).
} 
and Medium- Tech Manufacturing and knowledge intensive services is a consequence of the evolution of the selection forces at work in the US economy (see Autor et al, 2013).

Before concluding, a caveat is in order. The low correspondence between the taxonomies reviewed here is not necessarily a sign of weakness on either side. True, the arrangement of sectors today is not what it was, say, at the time of Pavitt's analysis. But we argue that this reaffirms the dynamic validity of taxonomic constructs. If we consider the 'logic' of arranging sectors by functional similarities, the sets of results reviewed here are arguably not ontologically dissimilar. Put otherwise, the enduring legacy of Pavitt's (1984) contribution is the intuition of classifying sectors through snapshots of knowledge organization, however imperfect they may be. Underpinning this heuristic model is the axiom that knowledge structures have transient nature: repeat the same exercise thirty years on and different configurations will be observed due to further evolution of the knowledge configurations.

\section{Concluding remarks}

Innovation scholars have often adopted industry classifications to grasp the characteristics of technological change and, more implicitly, of the underpinning organization of knowledge. This paper takes workforce skills as unit of analysis to detect commonalities and differences in the knowledge base of industry. Let us sum up the main results and reflect about future avenues of research that may stem from the present work.

First, we draw attention to the relation between labour, knowledge and the organization of industry, arguably an underdeveloped topic in innovation studies. In particular, we surmise that the skills content of the workforce is a reliable indicator of the knowledge that is relevant to an industry at any time. Accordingly, as industry needs evolve over time the occupational structures and the relevant skills are, so to speak, engaged in an open-ended chase along the trajectory of knowledge growth which, as argued elsewhere, calls upon institutional responses to fill emergent skill gaps (Rosenberg, 1998; Vona and Consoli, 2015). In this view evolving skill structures are both the cause and the effect of shifting industrial regimes based on the generation, adaptation and diffusion of useful knowledge.

The paper proposes a novel taxonomy of industrial sectors based on the analysis of the skill content of occupations across 290 sectors in the US. This empirical exercise yields two skill factors and three industry clusters. The former capture parsimoniously the co-existence of different types of knowledge distinguished functionally depending on whether skills are employed for non-routine cognitive tasks or for manual activities. In the latter, the industry 
clusters, service activities are present everywhere and exhibit strong complementarity with manufacturing production (Clusters 1 and 2) or stand alone in the construct with the stronger interactive nature (Cluster 3). This result resonates with recent research suggesting that the traditional dualism with manufacturing is perhaps obsolete (Castellacci, 2008; Peneder, 2007) and casts a shadow on the persistent view of services as a homogeneous block of activities (Consoli and Elche, 2010; 2013).

To conclude, there is no doubt that this work is but a preliminary step in an arguably promising trajectory. Greater understanding of industry-specific skill content opens important windows on policy issues concerning skill mismatches, knowledge gaps and on the role of education policy in responding to emergent industry needs. Growing availability of microlongitudinal data such as those used here bodes well for future endeavors in this area of study. The most enticing prospect, and our next goal, is to retrieve other industry dimensions, both economic (i.e. productivity, value added) and technological (i.e. patenting), to explore statistical regularities with the skill configurations. Attractive as these endeavours may appear, any future empirical exercise will need a prior effort of systematization of concepts and methods that, we hope, this paper contributes to outline.

\section{Acknowledgements}

Previous versions of this manuscript were presented at the 2012 International Conference "The Governance of a Complex World" in Nice (France); at the seminar series of INGENIO (CSIC-UPV) in Valencia (Spain); at the 2013 EU-SPRI international conference in Madrid (Spain); at the seminar series of the Department of Economics, University of Turin (Italy); and at the 2013 DRUID conference in Barcelona (Spain). On those and other occasions we benefited from useful feedback from Cristiano Antonelli, Fulvio Castellacci, Pablo D’Este, Charles Edquist, Claudio Fassio, Hanna Hottenrott, Aldo Geuna, Julia Lane, Alberto Marzucchi, Stan Metcalfe, Richard Nelson, Francois Perruchas, Pier Paolo Patrucco, Paula Stephan, Manuel Toselli and Richard Woolley, to whom we remain indebted. We are also grateful to two anonymous referees for the constructive criticism. DC would like to thank also Antonia Díaz, María Paz Espinosa and Sjaak Hurkens for setting an example of professional ethics. We are responsible for any error or omissions. 


\section{Bibliographic References}

Amable, B. (2003) The Diversity of Modern Capitalism. Oxford University Press, Oxford.

Antonelli, C. (2006) "The business governance of localized knowledge: an information economics approach for the economics of knowledge”. Industry and Innovation 13(3): 227-261.

Archibugi, D. (2001) “Pavitt's Taxonomy Sixteen Years on: A Review Article”. Economics of Innovation and New Technology 3: 415-425.

Asheim, B.T. and Coenen, L. (2005) "Knowledge bases and regional innovation systems: Comparing Nordic clusters”. Research Policy 34(8): 1173-1190.

Autor, D., Levy, F., Murnane, R. (2003) “The skill content of recent technological change: an empirical exploration”. Quarterly Journal of Economics 118: 1279-1333.

Autor, D., Dorn, D. and Hanson, G.H. (2013) "Untangling trade and technology: evidence from local labor markets”. NBER Working Paper 18938.

Baldwin, R. (2011) “Trade and industrialisation after globalisation’s 2nd unbundling: How building and joining a supply chain are different and why it matters”. NBER Working Paper 17716.

Bartel, A. and Lichtenberg, F. (1987) “The Comparative Advantage of Educated Workers in Implementing New Technology”. Review of Economics and Statistics 64: 1-11.

Bottazzi, G., Cefis, E., Dosi, G. (2002) "Corporate growth and industrial structure. some evidence from the Italian manufacturing industry”. Industrial and Corporate Change, 11, 705-723.

Breschi, S., Malerba, F., Orsenigo, L. (2000) “Technological regimes and Schumpeterian patterns of innovation”. Economic Journal 110: 388-410.

Carlsson, W.B., Jacobsson, S., Holmén, M., Rickne, A. (2002) "Innovations systems: analytical and methodological issues”. Research Policy 31: 233-245.

Castaldi, C. (2009) "The relative weight of manufacturing and services in Europe: an innovation perspective”. Technological Forecasting and Social Change 76(6): 709-722.

Castellacci, F. (2007) “Technological regimes and sectoral differences in productivity growth”. Industrial and Corporate Change 16 (6): 1105-1145.

Castellacci, F. (2008) “Technological paradigms, regimes and trajectories: manufacturing and service industries in a new taxonomy of sectoral patterns of innovation”. Research Policy 37(6-7): 978-994.

Castellacci, F., Archibugi, D. (2008) “The technology clubs: The distribution of knowledge across nations”. Research Policy 37(10): 1659-1673.

Cohen, W.M., Levinthal, D.A. (1989) “Innovation and learning: the two faces of R\&D”. Economic Journal 99: 569-596

Consoli, D., Elche-Hortelano, D. (2010) "Variety in the knowledge base of Knowledge Intensive Business Services”. Research Policy 39(10): 1303-1310.

Consoli, D., Elche, D. (2013) “The Evolving Knowledge base of Professional Service Sectors”. Journal of Evolutionary Economics, 23(2): 477-501.

Consoli, D., Vona, F. and Rentocchini, F. (2014) "That was then, this is now: Skills and Routinization in the 2000s”. SPRU Working Paper SWPS 2014-18.

Cooke, P., Uranga, M., Etxebarria, G. (1997) “Regional Innovation Systems: Institutional and Organisational Dimensions”. Research Policy, 26: 47-491.

Cowan, R., David, P.A. and Foray, D. (2000) "The explicit economics of knowledge codification and tacitness”. Industrial and Corporate Change 9(2): 211-253. 
David, P.A. (2000) “Understanding digital technology’s evolution and the path of measured productivity growth: Present and future in the mirror of the past”. In: E. Brynolfsson and B. Kahin (eds.) Understanding the digital economy, MIT Press, Cambridge MA.

Edquist, C., Hommen, L., McKelvey, M. (2001) Systems of Innovation: Growth, Competitiveness and Employment. Cheltenham: Edward Elgar.

Evangelista, R., Perani, G., Rapiti, F., Archibugi, D. (1997) "Nature and impact of innovation in manufacturing industries: some evidence from the Italian innovation survey”. Research Policy 26: 521-536.

Fabricant, S. (1972) "Productivity in the Tertiary Sector”. Supplement to NBER Report Ten: Productivity in the Tertiary Sector.

Foray, D. (2004) The Economics of Knowledge. MIT Press

Freel, M. (2005) “Patterns of innovation and skills in small firms”. Technovation 25(2): 123-134.

Freeman, C., Clark, J., Soete, L. (1982) Unemployment and Technical Innovation, London Pinter.

Galor, O., Moav, O. (2000) "Ability-biased technological transition, wage inequality, and economic growth”. Quarterly Journal of Economics 115: 469-497.

Geroski, P.A., Machin, S., Van Reenen, J. (1993) “The profitability of innovating firms”. Rand Journal of Economics 24(2): 198-211.

Giuri, P., Ploner, M., Rullani, F., Torrisi, S. (2010) “Skills, division of labor and performance in collective inventions: evidence from open source software”. International Journal of Industrial Organization 28(1): 54-68.

Godin, B. (2004) "The obsession for competitiveness and its impact on statistics: The construction of high-technology indicators”. Research Policy 33(8): 1217-1229.

Goldin, C., Katz, L.F. (2008) The race between education and technology. Harvard University Press, Cambridge, Massachusetts.

Gorsuch, R. (1983) Factor Analysis. L. Erlbaum Associates.

Henderson, R., Cockburn, I. (1996) "Scale, scope, and spillovers: the determinants of research productivity in drug discovery”. Rand Journal of Economics 27(1): 32-59.

Howell, D., Wolff, E. (1992) “Technical change and the demand for skills by US industries”. Cambridge Journal of Economics 16: 128-146.

Jensen, M. B., Johnson, B., Lorenz, E., and Lundvall, B.Å. (2007) "Forms of knowledge and modes of innovation”. Research Policy 36(5): 680-693.

Johnson, J., Baldwin, J., Diverty, B. (1996) “The implications of innovation for human resource strategies". Futures 28: 103-119.

Kogut, B., Zander, U. (1992) "Knowledge of the firm, combinative capabilities, and the replication of technology”. Organization Science 3(3): 383-397.

Krafft, J., Quatraro, F., Saviotti, P.P. (2011) “The Knowledge-base Evolution of Biotechnology: a Social Network Analysis”. Economics of Innovation and New Technology 20(5): 445-475.

Lavoie, M., Therrien, P. (2005) "Different strokes for different folks: examining the effects of computerization on Canadian workers”. Technovation 25(8): 883-894.

Leiponen, A. (2005) "Skills and innovation”. International Journal of Industrial Organization 23: 303-323.

Leiponen, A., Drejer, I. (2007) "What exactly are technological regimes? Intra-industry heterogeneity in the organization of innovation activities”. Research Policy 36 (8): 1221-1238. 
Levy, F., Murnane, R.J. (2004) The new division of labor: how computers are creating the next job market. Russell Sage Foundation, Princeton University Press.

Los, B., Verspagen, B. (2004) “Technology spillovers and their impact on productivity”. In: Hanusch, H., Pyka, A. (eds) Elgar Companion to Neo-Schumpeterian Economics. Edward Elgar, Cheltenham.

Malerba, F. (2002) “Sectoral systems of innovation and production”. Research Policy 31: 247- 264.

Malerba, F. (2005) "Sectoral systems: how and why innovation differs across sectors". In: Fagerberg J, Mowery D, Nelson RR (eds) The Oxford handbook of innovation. Oxford University Press, Oxford.

Malerba, F., Montobbio, F. (2003) "Exploring factors affecting international technological specialization: the role of knowledge flows and the structure of innovative activity". Journal of Evolutionary Economics 13: 411-434.

Metcalfe, J.S. (2001) “Institutions and Progress”. Industrial and Corporate Change 10: 561-586.

Metcalfe J.S and Ramlogan, R. (2005) "Limits to the economy of knowledge and knowledge of the economy”. Futures 37: 655-674.

Metcalfe, J.S., Foster, J., Ramlogan, R. (2006) “Adaptive Economic Growth”. Cambridge Journal of Economics 30(1): 7-32.

Miles, I. (2005) “Innovation in Services”. In J. Fagerberg, D. Mowery, and R.R. Nelson (eds), The Oxford Handbook of Innovation, Oxford: Oxford University Press.

Miozzo, M., Soete, L. (2001) “Internationalization of Services: a Technological Perspective”. Technological Forecasting and Social Change 67: 159-185.

Mowery, D., Nelson, R.R. (1999) The Sources of Industrial Leadership. Cambridge University Press: Cambridge.

National Research Council (2010) A database for a changing economy: review of the Occupational Information Network $\left(O^{*} N E T\right)$. The National Academies Press, Washington, DC.

Neffke, F., Henning, M.S. (2013) “Skill-relatedness and firm diversification”. Strategic Management Journal 34(3): 297-316.

Nelson, R.R. (Ed.) (1993) National Systems of Innovation. A Comparative Analysis. Oxford University Press, Oxford.

Nelson R.R. (1994) “The co-evolution of technology, industrial structure and supporting institutions". Industrial and Corporate Change 3: 47-64.

Nelson, R.R., Winter, S.G. (1982) An Evolutionary Theory of Economic Change. Belknap Press, Cambridge, MA.

Oldenski, L. (2012) “Export versus FDI and the communication of complex information”, Journal of International Economics 87(2): 312-322.

Pavitt, K. (1984) "Sectoral patterns of technical change: towards a taxonomy and a theory". Research Policy 13 (6), 343-373.

Peneder, M. (2003) “Industry classifications: aim, scope and techniques”. Journal of Industry, Competition and Trade 3(1-2): 109-129.

Peneder, M. (2010) "Technological regimes and the variety of innovation behaviour: Creating integrated taxonomies of firms and sectors”. Research Policy 39(3): 323-334.

Petit, P., Soete, L. (2002) Technology and the Future of European Employment. Cheltenham: Edward Elgar.

Reichstein, T., Salter, A.J. (2006) "Investigating the sources of process innovation among UK manufacturing firms”. Industrial and Corporate Change 15(4): 653-682.

Richardson, G.B. (1972) “The Organisation of Industry”. Economic Journal 82 (327): 883-896. 
Rosenberg, N. (1976) Perspectives on Technology. Cambridge University Press.

Rosenberg, N. (1998) “Chemical engineering as a general purpose technology”. In: Helpman E. (ed.) General Purpose Technologies and Economic Growth. MIT, Cambridge MA.

Srholec, M., and Verspagen, B. (2012) "The Voyage of the Beagle into innovation: explorations on heterogeneity, selection, and sectors”. Industrial and Corporate Change, 21(5): 1221-1253.

Simon, H.A. (1969) The Sciences of the Artificial. MIT Press, Cambridge, Mass.

Thomson, G.H. (1951) The Factorial Analysis of Human Ability. London: University of London Press.

Van Dijk, M. (2000) "Technological Regimes and Industrial Dynamics: the Evidence from Dutch Manufacturing”. Industrial and Corporate Change 9: 173-194.

Vivarelli, M. (1995) The Economics of Technology and Employment: Theory and Empirical Evidence. Aldershot, Elgar.

Vona, F., Consoli, D. (2015) “Innovation and skill dynamics: a life-cycle approach”. Industrial and Corporate Change. Forthcoming.

Wolff, E.N. (2006) Does Education Really Help?: Skill, Work, and Inequality. Oxford University Press. 


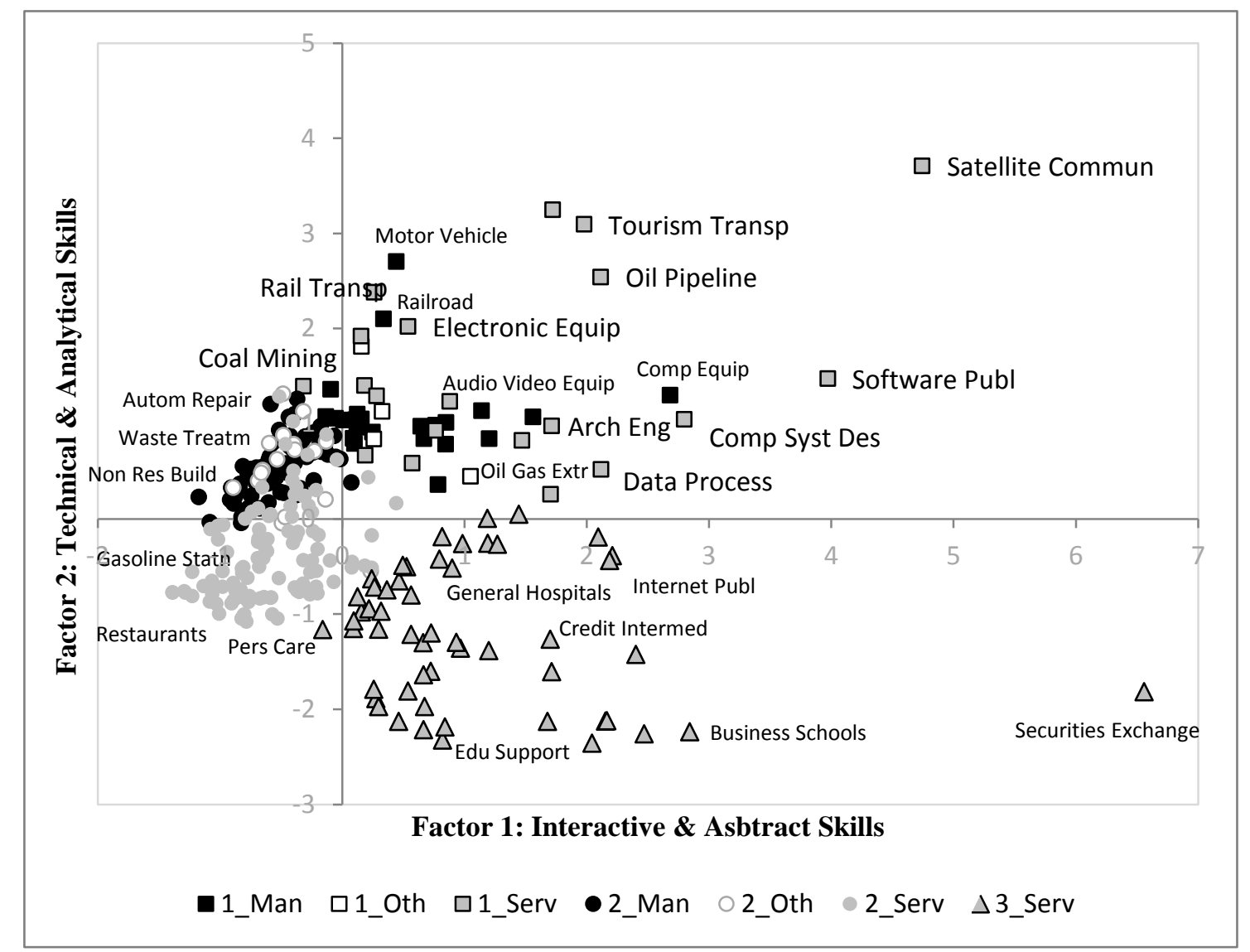

Note: industries are labeled according to two dimensions: cluster (shape) and type (color).

Legend: Square=Complex Production (Cluster 1); Circle=Basic Production and Distribution (Cluster 2); Triangle=People Services (Cluster 3); Black=Manufacturing; Gray=Services; White=Other (Agriculture, Mining, Utilities).

Figure 1: Industry Clusters by Skill Factors 

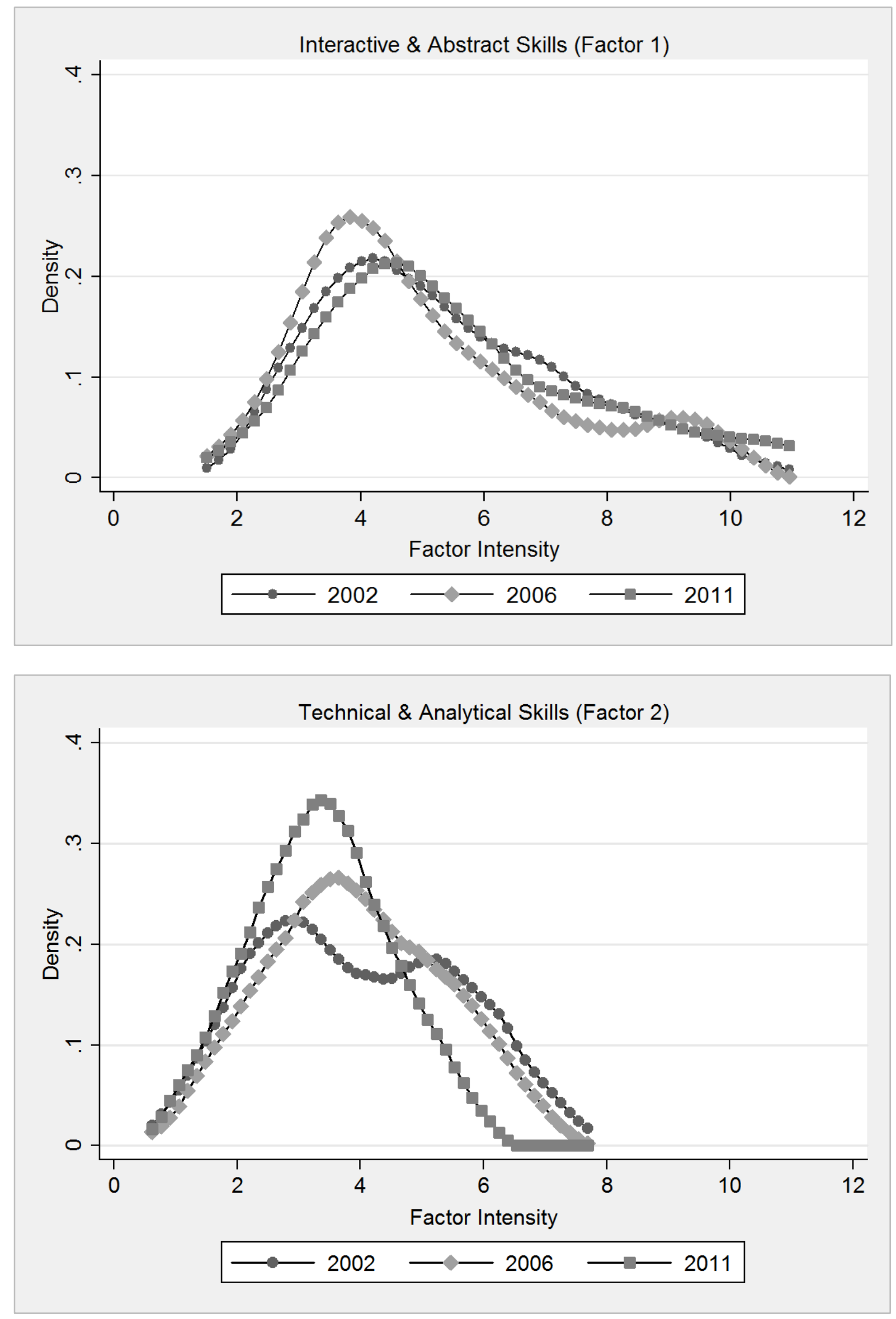

Figure 2: Kernel density distributions of Skill-Factors intensity across industries 


\begin{tabular}{|c|c|c|c|c|c|c|c|}
\hline & & $\begin{array}{c}\text { Prin } \\
\text { Comp }\end{array}$ & $\begin{array}{l}\text { ipal } \\
\text { nent }\end{array}$ & $\begin{array}{r}\text { Iterated } \\
\text { Fac } \\
\end{array}$ & $\begin{array}{l}\text { rincipal } \\
\text { ors }\end{array}$ & $\begin{array}{l}\text { Max } \\
\text { Like }\end{array}$ & $\begin{array}{l}\text { mum } \\
\text { ihood }\end{array}$ \\
\hline & & Factor1 & Factor2 & Factor1 & Factor2 & Factor1 & Factor2 \\
\hline & Active Learning & 0.9427 & 0.322 & 0.9428 & 0.3241 & 0.9244 & 0.3742 \\
\hline & Active Listening & 0.9736 & 0.1897 & 0.974 & 0.1909 & 0.9722 & 0.2203 \\
\hline & Complex Problem Solving & 0.9101 & 0.4001 & 0.9095 & 0.4028 & 0.8808 & 0.4654 \\
\hline & Coordination & 0.927 & 0.3382 & 0.9262 & 0.3404 & 0.9179 & 0.3584 \\
\hline & Critical Thinking & 0.9464 & 0.3105 & 0.9466 & 0.3124 & 0.9302 & 0.3614 \\
\hline & Instructing & 0.9216 & 0.156 & 0.9155 & 0.1611 & 0.9339 & 0.1509 \\
\hline & Judgment \& Decision Making & 0.9264 & 0.3553 & 0.926 & 0.3577 & 0.9046 & 0.4101 \\
\hline & Learning Strategies & 0.943 & 0.1881 & 0.9398 & 0.1913 & 0.9466 & 0.2002 \\
\hline & Mathematics & 0.7929 & 0.5464 & 0.7901 & 0.548 & 0.7452 & 0.627 \\
\hline & Manag of Financial Resources & 0.8822 & 0.3144 & 0.877 & 0.3176 & 0.8456 & 0.3902 \\
\hline$\underbrace{\pi}$ & Manag of Material Resources & 0.8277 & 0.5265 & 0.8258 & 0.5293 & 0.7964 & 0.5637 \\
\hline$-1 \stackrel{0}{\frac{0}{2}}$ & Manag of Personnel & 0.9216 & 0.3269 & 0.92 & 0.3294 & 0.9031 & 0.363 \\
\hline ठै & Monitoring & 0.9523 & 0.2731 & 0.9522 & 0.2749 & 0.9457 & 0.2986 \\
\hline 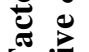 & Negotiation & 0.9578 & 0.2 & 0.9564 & 0.2024 & 0.9428 & 0.25 \\
\hline 玒 & Operations Analysis & 0.7981 & 0.5255 & 0.7949 & 0.5269 & 0.7376 & 0.6316 \\
\hline 苞 & Persuasion & 0.9753 & 0.1703 & 0.9754 & 0.1718 & 0.9608 & 0.2258 \\
\hline$\vec{\Xi}$ & Programming & 0.6437 & 0.4904 & 0.6371 & 0.4819 & 0.5586 & 0.6517 \\
\hline & Reading Comprehension & 0.9503 & 0.2899 & 0.9504 & 0.2918 & 0.9401 & 0.3314 \\
\hline & Science & 0.6526 & 0.5262 & 0.6475 & 0.5174 & 0.6338 & 0.5471 \\
\hline & Social Perceptiveness & 0.9633 & 0.0154 & 0.9603 & 0.0192 & 0.9786 & 0.0187 \\
\hline & Speaking & 0.9825 & 0.1438 & 0.9833 & 0.1446 & 0.9826 & 0.1749 \\
\hline & Service Orientation & 0.9608 & 0.0245 & 0.9574 & 0.0286 & 0.9723 & 0.0328 \\
\hline & Systems Analysis & 0.8132 & 0.5307 & 0.8108 & 0.533 & 0.7631 & 0.6153 \\
\hline & Systems Evaluation & 0.8417 & 0.5021 & 0.8398 & 0.5049 & 0.797 & 0.5785 \\
\hline & Time Management & 0.9566 & 0.2656 & 0.9567 & 0.2673 & 0.9491 & 0.2959 \\
\hline & Writing & 0.9716 & 0.2132 & 0.9722 & 0.2145 & 0.9627 & 0.2602 \\
\hline & Equipment Maintenance & -0.0035 & 0.941 & 0.0006 & 0.9277 & 0.0078 & 0.8072 \\
\hline 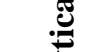 & Equipment Selection & 0.5784 & 0.7847 & 0.5761 & 0.7866 & 0.5526 & 0.7789 \\
\hline$\frac{\sqrt{\pi}}{\pi}$ & Installation & 0.2513 & 0.9222 & 0.251 & 0.9176 & 0.2118 & 0.9106 \\
\hline$\approx E$ & Operation and Control & 0.2197 & 0.8961 & 0.2233 & 0.8808 & 0.2259 & 0.7946 \\
\hline 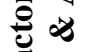 & Operation Monitoring & 0.1511 & 0.9346 & 0.1529 & 0.9253 & 0.1457 & 0.8504 \\
\hline 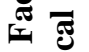 & Quality Control Analysis & 0.5373 & 0.8184 & 0.5348 & 0.8213 & 0.4934 & 0.8476 \\
\hline 光 & Repairing & -0.0656 & 0.9425 & -0.0618 & 0.9302 & -0.0675 & 0.8328 \\
\hline $\bar{z}$ & Technology Design & 0.6143 & 0.7112 & 0.6121 & 0.7081 & 0.5541 & 0.7895 \\
\hline & Troubleshooting & 0.4013 & 0.9022 & 0.398 & 0.9075 & 0.3626 & 0.9023 \\
\hline & \% of variance explained & 0.5824 & 0.2488 & 0.5446 & 0.3058 & 0.5768 & 0.256 \\
\hline & Cumulative \% of var expl & 0.5824 & 0.8312 & 0.5446 & 0.8504 & 0.5768 & 0.8328 \\
\hline
\end{tabular}

Rotation method: Varimax with Kaiser normalization.

Table 1: Factor Analysis 


\begin{tabular}{|c|c|c|c|}
\hline & $\begin{array}{c}\text { Complex Production } \\
\text { and Distribution } \\
\text { (CL1) }\end{array}$ & $\begin{array}{c}\text { Basic Production } \\
\text { and Distribution } \\
\text { (CL2) }\end{array}$ & $\begin{array}{c}\text { People Services } \\
\text { (CL3) }\end{array}$ \\
\hline \multirow{2}{*}{$\begin{array}{l}\text { Interactive \& Abstract } \\
\text { Skills }\end{array}$} & $0.1161^{* * *}$ & $-0.2481^{* * *}$ & $0.1320^{* * *}$ \\
\hline & {$[0.0243]$} & {$[0.0298]$} & {$[0.0211]$} \\
\hline \multirow{2}{*}{$\begin{array}{l}\text { Technical \& Analytical } \\
\text { Skills }\end{array}$} & $0.2212^{* * *}$ & -0.0293 & $-0.1919 * * *$ \\
\hline & {$[0.0202]$} & {$[0.0247]$} & {$[0.0175]$} \\
\hline \multirow[t]{2}{*}{ Labour productivity } & 0.0049 & -0.0052 & 0.0003 \\
\hline & {$[0.0056]$} & {$[0.0069]$} & {$[0.0049]$} \\
\hline \multirow[t]{2}{*}{ Cap. Exp. OCM } & $0.0043^{* * *}$ & $-0.0045^{* *}$ & 0.0002 \\
\hline & {$[0.0015]$} & {$[0.0018]$} & {$[0.0013]$} \\
\hline \multirow[t]{2}{*}{ Cap. Exp. Infrastructures } & $-0.0024 * * *$ & $0.0019 * *$ & 0.0005 \\
\hline & {$[0.0008]$} & {$[0.0009]$} & {$[0.0007]$} \\
\hline \multirow[t]{2}{*}{ N. of firms } & 0.0005 & -0.0009 & 0.0004 \\
\hline & {$[0.0005]$} & {$[0.0006]$} & {$[0.0004]$} \\
\hline \multicolumn{4}{|l|}{ (Ref. Other) } \\
\hline \multirow[t]{2}{*}{ H-KIS } & $0.1303^{*}$ & $-0.3838 * * *$ & $0.2535^{* * *}$ \\
\hline & {$[0.0767]$} & {$[0.0941]$} & {$[0.0666]$} \\
\hline \multirow[t]{2}{*}{ H-TECH } & $0.6445^{* * *}$ & $-0.5002 * * *$ & -0.1442 \\
\hline & {$[0.1138]$} & {$[0.1396]$} & {$[0.0988]$} \\
\hline \multirow[t]{2}{*}{ L-KIS } & $0.1509 * *$ & -0.0684 & -0.0825 \\
\hline & {$[0.0653]$} & {$[0.0801]$} & {$[0.0567]$} \\
\hline \multirow[t]{2}{*}{ L-TECH } & $0.2063^{* *}$ & $-0.1932 *$ & -0.0131 \\
\hline & {$[0.0922]$} & [0.1131] & {$[0.0800]$} \\
\hline \multirow{2}{*}{ Constant } & -0.0935 & $0.9757 * * *$ & 0.1178 \\
\hline & {$[0.1563]$} & [0.1918] & {$[0.1357]$} \\
\hline N. of observations & 285 & 285 & 285 \\
\hline $\mathrm{R}^{2}$ & 0.5613 & 0.596 & 0.6941 \\
\hline
\end{tabular}

Tests of equality of coefficients

[Cluster 1] Factor 1 vs [Cluster 3] Factor $1 \quad \chi^{2}(1)=0.17$

[Cluster 1] Factor 1 vs [Cluster 1] Factor $2 \quad \chi^{2}(1)=8.5^{* * *}$

${ }^{*} \mathrm{p}<0.10,{ }^{* *} \mathrm{p}<0.05,{ }^{* * *} \mathrm{p}<0.01$. Degrees of freedom and robust standard errors are in parentheses.

Capital Expenditures in Office and Computing Machinery (OCM) and in infrastructures both measured in million \$. Other=Agriculture, Mining, Utilities. H-KIS: High Knowledge Intensive Services; H-TECH=Hi-Tech Manufacturing; L-KIS=Low Knowledge Intensive Services; L-TECH: Low-Tech Manufacturing.

Table 2: Multivariate Regression 


\begin{tabular}{lccc}
\hline & $\begin{array}{c}\text { Complex Production } \\
\text { and Distribution }\end{array}$ & $\begin{array}{c}\text { Basic Production } \\
\text { and Distribution }\end{array}$ & People Services \\
\hline NPS & $23 \%$ & $48 \%$ & $22 \%$ \\
PS & $19 \%$ & $8 \%$ & $76 \%$ \\
SB & $13 \%$ & $0 \%$ & $0 \%$ \\
SD & $2 \%$ & $19 \%$ & $2 \%$ \\
SI & $29 \%$ & $22 \%$ & $0 \%$ \\
SS & $15 \%$ & $4 \%$ & $0 \%$ \\
\hline Total & 48 & 185 & 54 \\
\hline Pearson $\chi^{2}$ & \multicolumn{4}{l}{ 166.48(10)*** } \\
\hline$* * *$ p<0.01. Degrees of freedom are in parentheses. Personal Services (PS); Non-Personal \\
Services (NPS); Scale-Intensive (SI); Supplier-Dominated (SD); Science-Based (SB); \\
Specialised Supplier (SS)
\end{tabular}

Table 3a: Pavitt-Miozzo-Soete taxonomy: cross-tabulation

\begin{tabular}{|c|c|c|c|c|}
\hline & People Services & PS & $\begin{array}{l}\text { Basic Production } \\
\text { and Distribution }\end{array}$ & NPS \\
\hline \multirow{2}{*}{ Interactive \& Abstract Skills } & $0.1320 * * *$ & 0.0063 & $-0.2481^{* * *}$ & -0.0095 \\
\hline & [0.0379] & [0.0403] & {$[0.0560]$} & {$[0.0406]$} \\
\hline \multirow[t]{2}{*}{ Technical \& Analytical Skills } & $-0.1919 * * *$ & -0.0319 & -0.0293 & -0.0014 \\
\hline & {$[0.0251]$} & {$[0.0268]$} & {$[0.0403]$} & {$[0.0335]$} \\
\hline \multirow[t]{2}{*}{ Labour productivity } & 0.0003 & $0.0156^{* *}$ & -0.0052 & -0.0125 \\
\hline & [0.0047] & [0.0069] & [0.0079] & [0.0087] \\
\hline \multirow[t]{2}{*}{ Cap. Exp. OCM } & 0.0002 & 0.0012 & $-0.0045^{* *}$ & -0.0009 \\
\hline & {$[0.0015]$} & {$[0.0016]$} & {$[0.0019]$} & {$[0.0018]$} \\
\hline \multirow[t]{2}{*}{ Cap. Exp. Infrastructures } & 0.0005 & $0.0017 * * *$ & 0.0019 & $-0.0012 *$ \\
\hline & {$[0.0006]$} & {$[0.0006]$} & [0.0012] & {$[0.0006]$} \\
\hline \multirow[t]{2}{*}{ N. of firms } & 0.0004 & $0.0016^{* *}$ & $-0.0009 * *$ & $-0.0017 * *$ \\
\hline & {$[0.0005]$} & {$[0.0007]$} & {$[0.0004]$} & {$[0.0007]$} \\
\hline \multirow[t]{2}{*}{ H-KIS } & $0.2535^{* * *}$ & $0.6839 * * *$ & $-0.3838 * * *$ & 0.0956 \\
\hline & {$[0.0900]$} & [0.0934] & {$[0.1150]$} & [0.1234] \\
\hline \multirow[t]{2}{*}{ H-TECH } & $-0.1442 *$ & $-0.1977 * * *$ & $-0.5002 * * *$ & -0.0063 \\
\hline & {$[0.0776]$} & [0.0693] & [0.1567] & [0.1161] \\
\hline \multirow[t]{2}{*}{ L-KIS } & $-0.0825^{* *}$ & $0.1656 * * *$ & -0.0684 & $0.6262 * * *$ \\
\hline & {$[0.0386]$} & {$[0.0516]$} & {$[0.0676]$} & {$[0.0961]$} \\
\hline \multirow[t]{2}{*}{ L-TECH } & -0.0131 & $-0.1053^{*}$ & -0.1932 & -0.0898 \\
\hline & {$[0.0597]$} & {$[0.0618]$} & [0.1209] & {$[0.1079]$} \\
\hline \multirow[t]{2}{*}{ Constant } & 0.1178 & $-0.4826^{* *}$ & $0.9757 * * *$ & $0.5525^{* *}$ \\
\hline & {$[0.1291]$} & {$[0.1913]$} & {$[0.1859]$} & {$[0.2237]$} \\
\hline N. of observations & 285 & 285 & 285 & 285 \\
\hline $\mathrm{R}^{2}$ & 0.6941 & 0.547 & 0.596 & 0.5832 \\
\hline Breusch-Pagan & \multicolumn{2}{|c|}{$\chi^{2}(1)=9.443^{* * *}$} & \multicolumn{2}{|c|}{$\chi^{2}(1)=1.698$} \\
\hline \multicolumn{5}{|l|}{ Tests of equality of coefficients } \\
\hline [SK] Factor 1 vs [PMS] Factor 1 & \multicolumn{2}{|c|}{$\chi 2(1)=6.89 * * *$} & \multicolumn{2}{|c|}{$\chi 2(1)=14.02 * * *$} \\
\hline [SK] Factor 2 vs [PMS] Factor 2 & \multicolumn{2}{|c|}{$\chi 2(1)=21.28 * * *$} & \multicolumn{2}{|c|}{$\chi 2(1)=0.34$} \\
\hline
\end{tabular}

${ }^{*} \mathrm{p}<0.10,{ }^{* *} \mathrm{p}<0.05, * * * \mathrm{p}<0.01$. Degrees of freedom and robust standard errors are in parentheses. SK=Skill taxonomy, PMS= Pavitt Miozzo and Soete taxonomy. Personal Services (PS), Non-Personal Services (NPS).

Table 3b: Pavitt-Miozzo-Soete taxonomy: multivariate regression 


\begin{tabular}{lccc}
\hline & $\begin{array}{c}\text { Complex Production } \\
\text { and Distribution }\end{array}$ & $\begin{array}{c}\text { Basic Production } \\
\text { and Distribution }\end{array}$ & People Services \\
\hline AKP & $33 \%$ & $5 \%$ & $15 \%$ \\
MPG & $25 \%$ & $21 \%$ & $0 \%$ \\
PGS & $13 \%$ & $55 \%$ & $56 \%$ \\
SIS & $29 \%$ & $19 \%$ & $30 \%$ \\
\hline Total & 48 & 185 & 54 \\
\hline Pearson $\chi^{2}$ & $58.03(6) * * *$ \\
\hline$* * *$ p $<0.01$. Degrees of freedom are in parentheses. Advanced Knowledge Providers (AKP), \\
Mass production Goods (MPG), Supporting Infrastructure Services (SIS) Personal Goods \\
and Services (PGS).
\end{tabular}

Table 4a: Castellacci taxonomy: cross-tabulation

\begin{tabular}{|c|c|c|c|c|}
\hline & $\begin{array}{l}\text { Basic Production } \\
\text { and Distribution }\end{array}$ & PGS & People Services & PGS \\
\hline \multirow[t]{2}{*}{ Interactive \& Abstract Skills } & $-0.2481^{* * *}$ & $0.0513^{*}$ & $0.1320 * * *$ & $0.0513^{*}$ \\
\hline & {$[0.0560]$} & {$[0.0278]$} & [0.0379] & {$[0.0278]$} \\
\hline \multirow[t]{2}{*}{ Technical \& Analytical Skills } & -0.0293 & $-0.1705^{* * *}$ & $-0.1919 * * *$ & $-0.1705^{* * *}$ \\
\hline & [0.0403] & [0.0279] & [0.0251] & [0.0279] \\
\hline \multirow[t]{2}{*}{ Labour productivity } & -0.0052 & $-0.0358 * * *$ & 0.0003 & $-0.0358 * * *$ \\
\hline & [0.0079] & [0.0088] & [0.0047] & [0.0088] \\
\hline \multirow[t]{2}{*}{ Cap. Exp. OCM } & $-0.0045^{* *}$ & 0.0032 & 0.0002 & 0.0032 \\
\hline & [0.0019] & [0.0027] & [0.0015] & [0.0027] \\
\hline \multirow{2}{*}{ Cap. Exp. Infrastructures } & 0.0019 & $-0.0060 * * *$ & 0.0005 & $-0.0060 * * *$ \\
\hline & {$[0.0012]$} & {$[0.0012]$} & {$[0.0006]$} & {$[0.0012]$} \\
\hline \multirow[t]{2}{*}{ N. of firms } & $-0.0009 * *$ & 0.0008 & 0.0004 & 0.0008 \\
\hline & [0.0004] & [0.0008] & [0.0005] & {$[0.0008]$} \\
\hline \multirow[t]{2}{*}{ H-KIS } & $-0.3838 * * *$ & $-0.2433 *$ & $0.2535^{* * *}$ & $-0.2433^{*}$ \\
\hline & [0.1150] & [0.1384] & [0.0900] & [0.1384] \\
\hline \multirow[t]{2}{*}{ H-TECH } & $-0.5002 * * *$ & 0.2369 & $-0.1442 *$ & 0.2369 \\
\hline & {$[0.1567]$} & {$[0.1690]$} & {$[0.0776]$} & [0.1690] \\
\hline \multirow[t]{2}{*}{ L-KIS } & -0.0684 & -0.0741 & $-0.0825^{* *}$ & -0.0741 \\
\hline & {$[0.0676]$} & [0.1359] & {$[0.0386]$} & [0.1359] \\
\hline \multirow[t]{2}{*}{ L-TECH } & -0.1932 & $0.4268 * *$ & -0.0131 & $0.4268 * *$ \\
\hline & [0.1209] & {$[0.1742]$} & [0.0597] & {$[0.1742]$} \\
\hline \multirow[t]{2}{*}{ Constant } & $0.9757 * * *$ & $1.5006^{* * *}$ & 0.1178 & $1.5006 * * *$ \\
\hline & [0.1859] & [0.2839] & [0.1291] & [0.2839] \\
\hline N. of observations & 285 & 285 & 285 & 285 \\
\hline $\mathrm{R}^{2}$ & 0.596 & 0.372 & 0.6941 & 0.372 \\
\hline Breusch-Pagan & \multicolumn{2}{|c|}{$\chi 2(1)=1.17$} & \multicolumn{2}{|c|}{$\chi 2(1)=1.08$} \\
\hline \multicolumn{5}{|l|}{ Tests of equality of coefficients } \\
\hline [SK] Factor 1 vs [CASTEL] Factor 1 & \multicolumn{2}{|c|}{$\chi 2(1)=27.44 * * *$} & \multicolumn{2}{|c|}{$\chi 2(1)=2.71^{*}$} \\
\hline [SK] Factor 2 vs [CASTEL] Factor 2 & \multicolumn{2}{|c|}{$\chi 2(1)=9.86^{* * *}$} & \multicolumn{2}{|c|}{$\chi 2(1)=0.34$} \\
\hline
\end{tabular}

${ }^{*} \mathrm{p}<0.10,{ }^{* *} \mathrm{p}<0.05, * * * \mathrm{p}<0.01$. Degrees of freedom and robust standard errors are in parentheses. SK=Skill taxonomy, CASTEL= Castellacci taxonomy. Personal Goods and Services (PGS).

Table 4b: Castellacci taxonomy: multivariate regression 


\section{Appendix A}

O*NET, the Occupational Information Network, is a database of worker attributes and job characteristics maintained by the U.S. Department of Labor (DOL) and the National Center for O*NET Development, through its contractor Research Triangle Institute. It is the replacement for the Dictionary of Occupational Titles (DOT) and the primary source of occupational information for the US labour market. Data Collection is carried out in two steps: (1) identification of a random sample of businesses expected to employ workers in the targeted occupations, and (2) selection of a random sample of workers in those occupations within those businesses. New data are collected by means of a survey circulated among job incumbents (National Research Council, 2010). Occupations in O*NET are defined according to the criteria of the Standard Occupational Classification (SOC) system. Data Collection provides descriptive ratings based on the questionnaire covering various aspects of the occupation: Worker Characteristics, Worker Requirements, Experience Requirements, Occupation Requirements, Occupational Characteristics, and Occupation-Specific Information. In addition to the questionnaires completed by workers and occupation experts, additional ratings are provided by occupation analysts. Responses from all three sources - workers, occupation experts, and occupation analysts - are used to provide complete information for each occupation. The standardized skill set on which the questionnaire is built contains the categories reported in the table below.

\begin{tabular}{|c|c|}
\hline I. Basic Skills & IV. Social Skills \\
\hline Active Learning & Coordination \\
\hline Active Listening & Instructing \\
\hline Critical Thinking & Negotiation \\
\hline Learning Strategies & Persuasion \\
\hline Mathematics & Service Orientation \\
\hline Monitoring & Social Perceptiveness \\
\hline Reading Comprehension & V. Systems Skills \\
\hline Science & Judgment and Decision Making \\
\hline Speaking & Systems Analysis \\
\hline Writing & Systems Evaluation \\
\hline II. Complex Problem Solving Skills & VI. Technical Skills \\
\hline Complex Problem Solving & Equipment Maintenance \\
\hline III. Resource Management Skills & Equipment Selection \\
\hline Management of Financial Resources & Installation \\
\hline Management of Material Resources & Operation and Control \\
\hline Management of Personnel Resources & Operation Monitoring \\
\hline \multirow[t]{6}{*}{ Time Management } & Operations Analysis \\
\hline & Programming \\
\hline & Quality Control Analysis \\
\hline & Repairing \\
\hline & Troubleshooting \\
\hline & Technology Design \\
\hline
\end{tabular}




\section{Appendix B}

(Legenda: SK= Skill taxonomy; FC=Fulvio Castellacci; PMS=Pavitt, Miozzo and Soete; F1= Interactive \& Abstract Skills, F2= Technical \& Analytical Skills)

\begin{tabular}{|c|c|c|c|c|c|c|c|}
\hline NAICS & Description & F1 & $\mathbf{F 2}$ & Type & SK & FC & PMS \\
\hline 3334 & $\begin{array}{l}\text { Ventilation, Heating, Air-Conditioning, and Commercial Refrigeration } \\
\text { Equipment Manufacturing }\end{array}$ & 4.92 & 5.53 & L-TECH & Basic Production & AKP & SS \\
\hline 3339 & Other General Purpose Machinery Manufacturing & 5.54 & 5.25 & H-TECH & Basic Production & AKP & SS \\
\hline 5612 & Facilities Support Services & 4.94 & 3.53 & L-KIS & Basic Production & AKP & PS \\
\hline 3331 & Agriculture, Construction, and Mining Machinery Manufacturing & 5.00 & 5.24 & L-TECH & Basic Production & AKP & SS \\
\hline 5615 & Travel Arrangement and Reservation Services & 4.73 & 2.03 & L-KIS & Basic Production & AKP & NPS \\
\hline 3391 & Medical Equipment and Supplies Manufacturing & 4.73 & 4.30 & H-TECH & Basic Production & AKP & SS \\
\hline 5613 & Employment Services & 3.07 & 2.37 & H-KIS & Basic Production & AKP & PS \\
\hline 5614 & Business Support Services & 4.58 & 2.27 & L-KIS & Basic Production & AKP & PS \\
\hline 5419 & Other Professional, Scientific, and Technical Services & 6.08 & 3.62 & H-KIS & Basic Production & AKP & PS \\
\hline 3328 & Coating, Engraving, Heat Treating, and Allied Activities & 3.83 & 4.24 & L-TECH & Basic Production & MPG & SI \\
\hline 3312 & Steel Product Manufacturing from Purchased Steel & 4.57 & 5.16 & L-TECH & Basic Production & MPG & SI \\
\hline 3362 & Motor Vehicle Body and Trailer Manufacturing & 4.30 & 4.81 & L-TECH & Basic Production & MPG & SI \\
\hline 3351 & Electric Lighting Equipment Manufacturing & 5.31 & 5.21 & L-TECH & Basic Production & MPG & SS \\
\hline 3272 & Glass and Glass Product Manufacturing & 3.69 & 4.40 & L-TECH & Basic Production & MPG & SI \\
\hline 3372 & Office Furniture (including Fixtures) Manufacturing & 4.72 & 4.89 & L-TECH & Basic Production & MPG & SD \\
\hline 3211 & Sawmills and Wood Preservation & 3.02 & 3.86 & L-TECH & Basic Production & MPG & SD \\
\hline 3273 & Cement and Concrete Product Manufacturing & 3.47 & 3.78 & L-TECH & Basic Production & MPG & SI \\
\hline 3371 & Household and Institutional Furniture and Kitchen Cabinet Manufacturing & 3.15 & 3.87 & L-TECH & Basic Production & MPG & SD \\
\hline 3259 & Other Chemical Product and Preparation Manufacturing & 5.71 & 5.23 & L-TECH & Basic Production & MPG & SI \\
\hline 3359 & Other Electrical Equipment and Component Manufacturing & 5.10 & 5.15 & L-TECH & Basic Production & MPG & SD \\
\hline 3399 & Other Miscellaneous Manufacturing & 4.19 & 4.01 & L-TECH & Basic Production & MPG & SD \\
\hline 3315 & Foundries & 3.79 & 4.94 & L-TECH & Basic Production & MPG & SI \\
\hline 3329 & Other Fabricated Metal Product Manufacturing & 4.88 & 5.02 & L-TECH & Basic Production & MPG & SS \\
\hline 3323 & Architectural and Structural Metals Manufacturing & 4.63 & 4.93 & L-TECH & Basic Production & MPG & SI \\
\hline
\end{tabular}


3262 Rubber Product Manufacturing

3311 Iron and Steel Mills and Ferroalloy Manufacturing

3314 Nonferrous Metal (except Aluminium) Production and Processing

2123 Non-metallic Mineral Mining and Quarrying

L-TECH

3111 Animal Food Manufacturing

3113 Sugar and Confectionery Product Manufacturing

Production

MPG S

3116 Animal Slaughtering and Processing

3261 Plastics Product Manufacturing

3363 Motor Vehicle Parts Manufacturing

3279 Other Non-metallic Mineral Product Manufacturing

3271 Clay Product and Refractory Manufacturing

3112 Grain and Oilseed Milling

1152 Support Activities for Animal Production

2121 Coal Mining

1151 Support Activities for Crop Production

3321 Forging and Stamping

2131 Support Activities for Mining

1133 Logging

4529 Other General Merchandise Stores

3255 Paint, Coating, and Adhesive Manufacturing

4239 Miscellaneous Durable Goods Merchant Wholesalers 
7121 Museums, Historical Sites, and Similar Institutions

4532 Office Supplies, Stationery, and Gift Stores

8121 Personal Care Services

4244 Grocery and Related Product Wholesalers

7211 Traveler Accommodation

4421 Furniture Stores

3117 Seafood Product Preparation and Packaging

4441 Building Material and Supplies Dealers

4531 Florists

3159 Apparel Accessories and Other Apparel Manufacturing

3161 Leather and Hide Tanning and Finishing

8134 Civic and Social Organizations

2389 Other Specialty Trade Contractors

3212 Veneer, Plywood, and Engineered Wood Product Manufacturing

7213 Rooming and Boarding Houses

7212 RV (Recreational Vehicle) Parks and Recreational Camps

3121 Beverage Manufacturing

2383 Building Finishing Contractors

6233 Community Care Facilities for the Elderly

4511 Sporting Goods, Hobby, and Musical Instrument Stores

4235 Metal and Mineral (except Petroleum) Merchant Wholesalers

4543 Direct Selling Establishments

4248 Beer, Wine, and Distilled Alcoholic Beverage Merchant Wholesalers

7222 Limited-Service Eating Places

3151 Apparel Knitting Mills

3119 Other Food Manufacturing

4234 Professional and Commercial Equipment and Supplies Merchant Wholesalers

2372 Land Subdivision

4246 Chemical and Allied Products Merchant Wholesalers

7132 Gambling Industries

$\begin{array}{lllllc}5.70 & 2.89 & \text { H-KIS } & \text { Basic Production } & \text { PGS } & \text { NPS } \\ 4.26 & 2.16 & \text { L-KIS } & \text { Basic Production } & \text { PGS } & \text { NPS } \\ 3.90 & 1.82 & \text { L-KIS } & \text { Basic Production } & \text { PGS } & \text { NPS } \\ 3.05 & 2.00 & \text { L-KIS } & \text { Basic Production } & \text { PGS } & \text { NPS } \\ 2.19 & 1.57 & \text { L-KIS } & \text { Basic Production } & \text { PGS } & \text { NPS } \\ 3.80 & 1.92 & \text { L-KIS } & \text { Basic Production } & \text { PGS } & \text { NPS } \\ 2.96 & 3.16 & \text { L-TECH } & \text { Basic Production } & \text { PGS } & \text { SI } \\ 3.95 & 2.05 & \text { L-KIS } & \text { Basic Production } & \text { PGS } & \text { NPS } \\ 4.35 & 2.23 & \text { L-KIS } & \text { Basic Production } & \text { PGS } & \text { NPS } \\ 4.30 & 4.04 & \text { L-TECH } & \text { Basic Production } & \text { PGS } & \text { SD } \\ 4.45 & 4.64 & \text { L-TECH } & \text { Basic Production } & \text { PGS } & \text { SD } \\ 4.05 & 1.63 & \text { L-KIS } & \text { Basic Production } & \text { PGS } & \text { NPS } \\ 3.57 & 3.98 & \text { Other } & \text { Basic Production } & \text { PGS } & \text { SD } \\ 3.22 & 3.93 & \text { L-TECH } & \text { Basic Production } & \text { PGS } & \text { SD } \\ 3.61 & 2.40 & \text { L-KIS } & \text { Basic Production } & \text { PGS } & \text { NPS } \\ 4.08 & 2.56 & \text { L-KIS } & \text { Basic Production } & \text { PGS } & \text { NPS } \\ 3.30 & 2.96 & \text { L-TECH } & \text { Basic Production } & \text { PGS } & \text { SI } \\ 3.50 & 3.85 & \text { Other } & \text { Basic Production } & \text { PGS } & \text { SD } \\ 3.98 & 2.01 & \text { H-KIS } & \text { Basic Production } & \text { PGS } & \text { PS } \\ 3.49 & 1.70 & \text { L-KIS } & \text { Basic Production } & \text { PGS } & \text { NPS } \\ 5.37 & 3.84 & \text { L-KIS } & \text { Basic Production } & \text { PGS } & \text { NPS } \\ 4.06 & 3.44 & \text { L-KIS } & \text { Basic Production } & \text { PGS } & \text { NPS } \\ 5.30 & 2.72 & \text { L-KIS } & \text { Basic Production } & \text { PGS } & \text { NPS } \\ 1.74 & 1.00 & \text { L-KIS } & \text { Basic Production } & \text { PGS } & \text { NPS } \\ 3.38 & 4.05 & \text { L-TECH } & \text { Basic Production } & \text { PGS } & \text { SD } \\ 3.27 & 3.06 & \text { L-TECH } & \text { Basic Production } & \text { PGS } & \text { SI } \\ 7.53 & 5.19 & \text { L-KIS } & \text { Basic Production } & \text { PGS } & \text { NPS } \\ 7.29 & 3.83 & \text { Other } & \text { Basic Production } & \text { PGS } & \text { SD } \\ 5.61 & 3.58 & \text { L-KIS } & \text { Basic Production } & \text { PGS } & \text { NPS } \\ 2.91 & 1.65 & \text { L-KIS } & \text { Basic Production } & \text { PGS } & \text { NPS } \\ & & & & \end{array}$


3131 Fiber, Yarn, and Thread Mills

4481 Clothing Stores

7223 Special Food Services

5616 Investigation and Security Services

4243 Apparel, Piece Goods, and Notions Merchant Wholesalers

3118 Bakeries and Tortilla Manufacturing

4542 Vending Machine Operators

4539 Other Miscellaneous Store Retailers

4232 Furniture and Home Furnishing Merchant Wholesalers

3169 Other Leather and Allied Product Manufacturing

2373 Highway, Street, and Bridge Construction

7139 Other Amusement and Recreation Industries

4412 Other Motor Vehicle Dealers

3222 Converted Paper Product Manufacturing

4238 Machinery, Equipment, and Supplies Merchant Wholesalers

6231 Nursing Care Facilities

3221 Pulp, Paper, and Paperboard Mills

3256 Soap, Cleaning Compound, and Toilet Preparation Manufacturing

3114 Fruit and Vegetable Preserving and Specialty Food Manufacturing

3149 Other Textile Product Mills

3141 Textile Furnishings Mills

4413 Automotive Parts, Accessories, and Tire Stores

2381 Foundation, Structure, and Building Exterior Contractors

4233 Lumber and Other Construction Materials Merchant Wholesalers

4521 Department Stores

4512 Book, Periodical, and Music Stores

2362 Nonresidential Building Construction

2361 Residential Building Construction

3219 Other Wood Product Manufacturing

2371 Utility System Construction

3132 Fabric Mills

\begin{tabular}{llcllc}
3.42 & 5.20 & L-TECH & Basic Production & PGS & SD \\
3.20 & 1.36 & L-KIS & Basic Production & PGS & NPS \\
2.11 & 1.16 & L-KIS & Basic Production & PGS & NPS \\
3.60 & 2.37 & H-KIS & Basic Production & PGS & PS \\
5.88 & 2.97 & L-KIS & Basic Production & PGS & NPS \\
2.39 & 2.58 & L-TECH & Basic Production & PGS & SI \\
5.27 & 5.41 & L-KIS & Basic Production & PGS & NPS \\
3.60 & 1.98 & L-KIS & Basic Production & PGS & NPS \\
5.54 & 3.19 & L-KIS & Basic Production & PGS & NPS \\
4.67 & 4.16 & L-TECH & Basic Production & PGS & SD \\
4.40 & 4.76 & Other & Basic Production & PGS & SD \\
2.60 & 1.57 & L-KIS & Basic Production & PGS & NPS \\
4.93 & 4.24 & L-KIS & Basic Production & PGS & SI \\
3.64 & 4.12 & L-TECH & Basic Production & PGS & SD \\
5.10 & 4.15 & L-KIS & Basic Production & PGS & NPS \\
5.39 & 2.88 & H-KIS & Basic Production & PGS & PS \\
4.02 & 5.22 & L-TECH & Basic Production & PGS & SD \\
5.11 & 4.55 & L-TECH & Basic Production & PGS & SI \\
2.80 & 3.37 & L-TECH & Basic Production & PGS & SI \\
3.79 & 3.98 & L-TECH & Basic Production & PGS & SD \\
3.02 & 3.54 & L-TECH & Basic Production & PGS & SD \\
4.51 & 4.36 & L-KIS & Basic Production & PGS & NPS \\
3.92 & 4.42 & Other & Basic Production & PGS & SD \\
4.19 & 2.91 & L-KIS & Basic Production & PGS & NPS \\
3.09 & 1.47 & L-KIS & Basic Production & PGS & NPS \\
3.88 & 1.57 & L-KIS & Basic Production & PGS & NPS \\
5.54 & 4.39 & Other & Basic Production & PGS & SD \\
4.50 & 3.62 & Other & Basic Production & PGS & SD \\
3.00 & 3.58 & L-TECH & Basic Production & PGS & SD \\
4.41 & 5.46 & Other & Basic Production & PGS & SD \\
\hline .09 & L-TECH & Basic Production & PGS & SD
\end{tabular}


8123 Drycleaning and Laundry Services

2379 Other Heavy and Civil Engineering Construction

4236 Electrical and Electronic Goods Merchant Wholesalers

7131 Amusement Parks and Arcades

2382 Building Equipment Contractors

4422 Home Furnishings Stores

4533 Used Merchandise Stores

4461 Health and Personal Care Stores

4231 Motor Vehicle and Motor Vehicle Parts and Supplies Merchant Wholesalers

3115 Dairy Product Manufacturing

4471 Gasoline Stations

7221 Full-Service Restaurants

4451 Grocery Stores

4453 Beer, Wine, and Liquor Stores

4452 Specialty Food Stores

4245 Farm Product Raw Material Merchant Wholesalers

3162 Footwear Manufacturing

4431 Electronics and Appliance Stores

7113 Promoters of Performing Arts, Sports, and Similar Events

4249 Miscellaneous Nondurable Goods Merchant Wholesalers

4541 Electronic Shopping and Mail-Order Houses

3133 Textile and Fabric Finishing and Fabric Coating Mills

4251 Wholesale Electronic Markets and Agents and Brokers

4247 Petroleum and Petroleum Products Merchant Wholesalers

4237 Hardware, and Plumbing and Heating Equipment and Supplies Merchant Wholesalers

7112 Spectator Sports

3152 Cut and Sew Apparel Manufacturing

4483 Jewelry, Luggage, and Leather Goods Stores

4241 Paper and Paper Product Merchant Wholesalers

4242 Drugs and Druggists' Sundries Merchant Wholesalers

\begin{tabular}{|c|c|c|c|c|c|}
\hline 3.37 & 3.13 & L-KIS & Basic Production & PGS & NPS \\
\hline 5.24 & 5.28 & Other & Basic Production & PGS & SD \\
\hline 7.05 & 4.51 & L-KIS & Basic Production & PGS & NPS \\
\hline 3.43 & 2.01 & L-KIS & Basic Production & PGS & NPS \\
\hline 3.97 & 4.86 & Other & Basic Production & PGS & SD \\
\hline 3.67 & 2.00 & L-KIS & Basic Production & PGS & NPS \\
\hline 2.87 & 1.39 & L-KIS & Basic Production & PGS & NPS \\
\hline 7.07 & 4.18 & L-KIS & Basic Production & PGS & NPS \\
\hline 4.14 & 3.10 & L-KIS & Basic Production & PGS & NPS \\
\hline 2.84 & 3.17 & L-TECH & Basic Production & PGS & SI \\
\hline 3.52 & 1.92 & L-KIS & Basic Production & PGS & NPS \\
\hline 1.74 & 1.01 & L-KIS & Basic Production & PGS & NPS \\
\hline 2.34 & 1.24 & L-KIS & Basic Production & PGS & NPS \\
\hline 3.92 & 1.66 & L-KIS & Basic Production & PGS & NPS \\
\hline 3.14 & 1.79 & L-KIS & Basic Production & PGS & NPS \\
\hline 4.14 & 2.88 & L-KIS & Basic Production & PGS & NPS \\
\hline 3.40 & 3.55 & L-TECH & Basic Production & PGS & SD \\
\hline 5.52 & 3.88 & L-KIS & Basic Production & PGS & NPS \\
\hline 5.22 & 2.80 & H-KIS & Basic Production & PGS & NPS \\
\hline 3.62 & 2.23 & L-KIS & Basic Production & PGS & NPS \\
\hline 5.42 & 2.86 & L-KIS & Basic Production & PGS & NPS \\
\hline 4.01 & 4.16 & L-TECH & Basic Production & PGS & $\mathrm{SD}$ \\
\hline 4.67 & 2.65 & L-KIS & Basic Production & PGS & NPS \\
\hline 4.98 & 3.57 & L-KIS & Basic Production & PGS & NPS \\
\hline 5.51 & 3.39 & L-KIS & Basic Production & PGS & NPS \\
\hline 3.81 & 2.29 & H-KIS & Basic Production & PGS & NPS \\
\hline 3.38 & 3.34 & L-TECH & Basic Production & PGS & SD \\
\hline 3.78 & 1.89 & L-KIS & Basic Production & PGS & NP \\
\hline 5.72 & 3.29 & L-KIS & Basic Production & PGS & NP \\
\hline 5.82 & 2.98 & L-KIS & Basic Production & PGS & NP \\
\hline
\end{tabular}


8111 Automotive Repair and Maintenance

4482 Shoe Stores

3231 Printing and Related Support Activities

8129 Other Personal Services

4884 Support Activities for Road Transportation

5321 Automotive Equipment Rental and Leasing

4889 Other Support Activities for Transportation

5121 Motion Picture and Video Industries

4811 Scheduled Air Transportation

5324 Commercial and Industrial Machinery and Equipment Rental and Leasing

4854 School and Employee Bus Transportation

4921 Couriers

4831 Deep Sea, Coastal, and Great Lakes Water Transportation

5322 Consumer Goods Rental

4841 General Freight Trucking

5313 Activities Related to Real Estate

5323 General Rental Centers

4853 Taxi and Limousine Service

4883 Support Activities for Water Transportation

4842 Specialized Freight Trucking

4871 Scenic and Sightseeing Transportation, Land

5629 Remediation and Other Waste Management Services

4931 Warehousing and Storage

5622 Waste Treatment and Disposal

5619 Other Support Services

4872 Scenic and Sightseeing Transportation, Water

5621 Waste Collection

5312 Offices of Real Estate Agents and Brokers

4859 Other Transit and Ground Passenger Transportation

4885 Freight Transportation Arrangement

4922 Local Messengers and Local Delivery

$\begin{array}{lllllc}3.66 & 5.41 & \text { L-KIS } & \text { Basic Production } & \text { PGS } & \text { NPS } \\ 4.91 & 2.07 & \text { L-KIS } & \text { Basic Production } & \text { PGS } & \text { NPS } \\ 3.92 & 3.71 & \text { L-TECH } & \text { Basic Production } & \text { PGS } & \text { SD } \\ 2.80 & 1.75 & \text { L-KIS } & \text { Basic Production } & \text { PGS } & \text { PS } \\ 3.74 & 3.44 & \text { L-KIS } & \text { Basic Production } & \text { SIS } & \text { NPS } \\ 4.70 & 3.50 & \text { L-KIS } & \text { Basic Production } & \text { SIS } & \text { NPS } \\ 4.64 & 3.90 & \text { L-KIS } & \text { Basic Production } & \text { SIS } & \text { NPS } \\ 7.26 & 4.19 & \text { H-KIS } & \text { Basic Production } & \text { SIS } & \text { NPS } \\ 4.13 & 3.52 & \text { H-KIS } & \text { Basic Production } & \text { SIS } & \text { NPS } \\ 5.26 & 4.46 & \text { L-KIS } & \text { Basic Production } & \text { SIS } & \text { NPS } \\ 3.72 & 3.87 & \text { L-KIS } & \text { Basic Production } & \text { SIS } & \text { NPS } \\ 4.71 & 4.09 & \text { L-KIS } & \text { Basic Production } & \text { SIS } & \text { PS } \\ 6.72 & 5.24 & \text { L-KIS } & \text { Basic Production } & \text { SIS } & \text { NPS } \\ 3.53 & 1.75 & \text { L-KIS } & \text { Basic Production } & \text { SIS } & \text { NPS } \\ 2.66 & 2.62 & \text { L-KIS } & \text { Basic Production } & \text { SIS } & \text { NPS } \\ 5.31 & 3.17 & \text { L-KIS } & \text { Basic Production } & \text { SIS } & \text { PS } \\ 5.27 & 4.09 & \text { L-KIS } & \text { Basic Production } & \text { SIS } & \text { NPS } \\ 3.88 & 3.17 & \text { L-KIS } & \text { Basic Production } & \text { SIS } & \text { NPS } \\ 4.23 & 5.18 & \text { L-KIS } & \text { Basic Production } & \text { SIS } & \text { NPS } \\ 2.82 & 2.70 & \text { L-KIS } & \text { Basic Production } & \text { SIS } & \text { NPS } \\ 4.74 & 3.80 & \text { H-KIS } & \text { Basic Production } & \text { SIS } & \text { NPS } \\ 5.65 & 5.14 & \text { L-KIS } & \text { Basic Production } & \text { SIS } & \text { SD } \\ 2.74 & 2.41 & \text { L-KIS } & \text { Basic Production } & \text { SIS } & \text { NPS } \\ 4.96 & 4.15 & \text { L-KIS } & \text { Basic Production } & \text { SIS } & \text { SI } \\ 4.14 & 2.73 & \text { L-KIS } & \text { Basic Production } & \text { SIS } & \text { PS } \\ 4.76 & 4.19 & \text { L-KIS } & \text { Basic Production } & \text { SIS } & \text { NPS } \\ 3.57 & 3.26 & \text { L-KIS } & \text { Basic Production } & \text { SIS } & \text { NPS } \\ 4.61 & 2.24 & \text { L-KIS } & \text { Basic Production } & \text { SIS } & \text { PS } \\ 3.92 & 3.01 & \text { L-KIS } & \text { Basic Production } & \text { SIS } & \text { NPS } \\ 6.32 & 3.28 & \text { L-KIS } & \text { Basic Production } & \text { SIS } & \text { NPS } \\ 6.77 & 3.75 & \text { L-KIS } & \text { Basic Production } & \text { SIS } & \text { PS }\end{array}$


2213 Water, Sewage and Other Systems

5111 Newspaper, Periodical, Book, and Directory Publishers

5311 Lessors of Real Estate

4881 Support Activities for Air Transportation

4855 Charter Bus Industry

5617 Services to Buildings and Dwellings

4851 Urban Transit Systems

5112 Software Publishers

3254 Pharmaceutical and Medicine Manufacturing

3332 Industrial Machinery Manufacturing

5182 Data Processing, Hosting, and Related Services

3333 Commercial and Service Industry Machinery Manufacturing

3346 Manufacturing and Reproducing Magnetic and Optical Media

3335 Metalworking Machinery Manufacturing

3336 Engine, Turbine, and Power Transmission Equipment Manufacturing

3341 Computer and Peripheral Equipment Manufacturing

3345 Navigational, Measuring, Electromedical, and Control Instruments Manufacturing

3343 Audio and Video Equipment Manufacturing

3369 Other Transportation Equipment Manufacturing

3342 Communications Equipment Manufacturing

5415 Computer Systems Design and Related Services

5413 Architectural, Engineering, and Related Services

\begin{tabular}{|c|c|c|c|c|c|}
\hline 4.97 & 4.99 & Other & Basic Production & SIS & NPS \\
\hline 6.68 & 3.97 & H-KIS & Basic Production & SIS & SD \\
\hline 3.91 & 2.88 & L-KIS & Basic Production & SIS & PS \\
\hline 4.13 & 4.74 & L-KIS & Basic Production & SIS & NPS \\
\hline 4.83 & 4.96 & L-KIS & Basic Production & SIS & NPS \\
\hline 2.46 & 2.45 & L-KIS & Basic Production & SIS & PS \\
\hline 4.52 & 4.47 & L-KIS & Basic Production & SIS & NPS \\
\hline 18.94 & 12.30 & H-KIS & $\begin{array}{l}\text { Complex } \\
\text { Production }\end{array}$ & $\mathrm{AKP}$ & PS \\
\hline 8.66 & 5.98 & H-TECH & $\begin{array}{l}\text { Complex } \\
\text { Production }\end{array}$ & AKP & SB \\
\hline 7.74 & 6.84 & H-TECH & $\begin{array}{l}\text { Complex } \\
\text { Production }\end{array}$ & AKP & SS \\
\hline 13.12 & 8.19 & L-KIS & $\begin{array}{l}\text { Complex } \\
\text { Production }\end{array}$ & $\mathrm{AKP}$ & PS \\
\hline 7.89 & 6.68 & H-TECH & $\begin{array}{l}\text { Complex } \\
\text { Production }\end{array}$ & AKP & SS \\
\hline 8.55 & 6.89 & L-TECH & $\begin{array}{l}\text { Complex } \\
\text { Production }\end{array}$ & $\mathrm{AKP}$ & SD \\
\hline 5.52 & 5.97 & L-TECH & $\begin{array}{l}\text { Complex } \\
\text { Production }\end{array}$ & $\mathrm{AKP}$ & SS \\
\hline 5.88 & 6.21 & L-TECH & $\begin{array}{l}\text { Complex } \\
\text { Production }\end{array}$ & $\mathrm{AKP}$ & SS \\
\hline 14.57 & 10.25 & H-TECH & $\begin{array}{l}\text { Complex } \\
\text { Production }\end{array}$ & $\mathrm{AKP}$ & SI \\
\hline 9.75 & 7.41 & H-TECH & $\begin{array}{l}\text { Complex } \\
\text { Production }\end{array}$ & AKP & SB \\
\hline 9.37 & 7.89 & H-TECH & $\begin{array}{l}\text { Complex } \\
\text { Production }\end{array}$ & $\mathrm{AKP}$ & SB \\
\hline 6.03 & 6.20 & L-TECH & $\begin{array}{l}\text { Complex } \\
\text { Production }\end{array}$ & AKP & SI \\
\hline 10.85 & 8.33 & H-ТECH & $\begin{array}{l}\text { Complex } \\
\text { Production }\end{array}$ & AKP & SB \\
\hline 15.17 & 9.90 & H-KIS & $\begin{array}{l}\text { Complex } \\
\text { Production }\end{array}$ & AKP & PS \\
\hline 11.45 & 8.37 & H-KIS & $\begin{array}{l}\text { Complex } \\
\text { Production }\end{array}$ & AKP & PS \\
\hline
\end{tabular}




\begin{tabular}{|c|c|c|c|c|c|c|}
\hline 3344 & Semiconductor and Other Electronic Component Manufacturing & 8.15 & 6.96 & H-TECH & $\begin{array}{c}\text { Complex } \\
\text { Production }\end{array}$ & AKP \\
\hline 3353 & Electrical Equipment Manufacturing & 5.94 & 6.01 & L-TECH & $\begin{array}{l}\text { Complex } \\
\text { Production }\end{array}$ & MPG \\
\hline 3364 & Aerospace Product and Parts Manufacturing & 8.45 & 7.13 & H-TECH & $\begin{array}{l}\text { Complex } \\
\text { Production }\end{array}$ & MPG \\
\hline 3241 & Petroleum and Coal Products Manufacturing & 5.97 & 5.68 & L-TECH & $\begin{array}{l}\text { Complex } \\
\text { Production }\end{array}$ & MPG \\
\hline 3361 & Motor Vehicle Manufacturing & 6.10 & 9.16 & L-TECH & $\begin{array}{l}\text { Complex } \\
\text { Production }\end{array}$ & MPG \\
\hline 2111 & Oil and Gas Extraction & 9.56 & 6.55 & Other & $\begin{array}{l}\text { Complex } \\
\text { Production }\end{array}$ & MPG \\
\hline 3274 & Lime and Gypsum Product Manufacturing & 5.03 & 6.22 & L-TECH & $\begin{array}{l}\text { Complex } \\
\text { Production }\end{array}$ & MPG \\
\hline 2122 & Metal Ore Mining & 5.69 & 7.16 & Other & $\begin{array}{l}\text { Complex } \\
\text { Production }\end{array}$ & MPG \\
\hline 3365 & Railroad Rolling Stock Manufacturing & 6.09 & 8.07 & L-TECH & $\begin{array}{l}\text { Complex } \\
\text { Production }\end{array}$ & MPG \\
\hline 3324 & Boiler, Tank, and Shipping Container Manufacturing & 5.32 & 5.87 & L-TECH & $\begin{array}{l}\text { Complex } \\
\text { Production }\end{array}$ & MPG \\
\hline 3325 & Hardware Manufacturing & 5.88 & 6.11 & L-TECH & $\begin{array}{l}\text { Complex } \\
\text { Production }\end{array}$ & MPG \\
\hline 3251 & Basic Chemical Manufacturing & 6.47 & 6.01 & H-TECH & $\begin{array}{l}\text { Complex } \\
\text { Production }\end{array}$ & MPG \\
\hline 3366 & Ship and Boat Building & 5.02 & 5.76 & L-TECH & $\begin{array}{l}\text { Complex } \\
\text { Production }\end{array}$ & MPG \\
\hline 6212 & Offices of Dentists & 12.00 & 8.02 & H-KIS & $\begin{array}{l}\text { Complex } \\
\text { Production }\end{array}$ & PGS \\
\hline 3252 & $\begin{array}{l}\text { Resin, Synthetic Rubber, and Artificial Synthetic Fibers and Filaments } \\
\text { Manufacturing }\end{array}$ & 6.02 & 5.93 & L-TECH & $\begin{array}{l}\text { Complex } \\
\text { Production }\end{array}$ & PGS \\
\hline 8112 & Electronic and Precision Equipment Repair and Maintenance & 6.84 & 8.16 & L-KIS & $\begin{array}{l}\text { Complex } \\
\text { Production }\end{array}$ & PGS \\
\hline 3253 & Pesticide, Fertilizer, and Other Agricultural Chemical Manufacturing & 6.05 & 5.63 & L-TECH & $\begin{array}{l}\text { Complex } \\
\text { Production }\end{array}$ & PGS \\
\hline 8113 & $\begin{array}{l}\text { Commercial and Industrial Machinery and Equipment (except Automotive } \\
\text { and Electronic) Repair and Maintenance }\end{array}$ & 5.61 & 7.40 & L-KIS & $\begin{array}{l}\text { Complex } \\
\text { Production }\end{array}$ & PGS \\
\hline 8114 & Personal and Household Goods Repair and Maintenance & 4.27 & 5.93 & L-KIS & $\begin{array}{l}\text { Complex } \\
\text { Production }\end{array}$ & PGS \\
\hline
\end{tabular}


4879 Scenic and Sightseeing Transportation, Other

5174 Satellite Telecommunications

2212 Natural Gas Distribution

5152 Cable and Other Subscription Programming

4832 Inland Water Transportation

4812 Nonscheduled Air Transportation

4861 Pipeline Transportation of Crude Oil

4852 Interurban and Rural Bus Transportation

5179 Other Telecommunications

4862 Pipeline Transportation of Natural Gas

4869 Other Pipeline Transportation

4882 Support Activities for Rail Transportation

2211 Electric Power Generation, Transmission and Distribution

5171 Wired Telecommunications Carriers

5412 Accounting, Tax Preparation, Bookkeeping, and Payroll Services

5416 Management, Scientific, and Technical Consulting Services

5411 Legal Services

5417 Scientific Research and Development Services

5418 Advertising and Related Services

5511 Management of Companies and Enterprises

5414 Specialized Design Services

5611 Office Administrative Services

\begin{tabular}{|c|c|c|c|c|}
\hline 11.65 & 12.00 & H-KIS & $\begin{array}{l}\text { Complex } \\
\text { Production }\end{array}$ & SIS \\
\hline 20.38 & 17.38 & H-KIS & $\begin{array}{l}\text { Complex } \\
\text { Production }\end{array}$ & SIS \\
\hline 6.60 & 5.94 & Other & $\begin{array}{l}\text { Complex } \\
\text { Production }\end{array}$ & SIS \\
\hline 7.80 & 6.25 & H-KIS & $\begin{array}{l}\text { Complex } \\
\text { Production }\end{array}$ & SIS \\
\hline 6.12 & 6.59 & L-KIS & $\begin{array}{l}\text { Complex } \\
\text { Production }\end{array}$ & SIS \\
\hline 6.52 & 5.59 & H-KIS & $\begin{array}{l}\text { Complex } \\
\text { Production }\end{array}$ & SIS \\
\hline 12.14 & 11.26 & L-KIS & $\begin{array}{l}\text { Complex } \\
\text { Production }\end{array}$ & SIS \\
\hline 6.46 & 6.77 & L-KIS & $\begin{array}{l}\text { Complex } \\
\text { Production }\end{array}$ & SIS \\
\hline 10.73 & 7.82 & H-KIS & $\begin{array}{l}\text { Complex } \\
\text { Production }\end{array}$ & SIS \\
\hline 8.53 & 7.47 & L-KIS & $\begin{array}{l}\text { Complex } \\
\text { Production }\end{array}$ & SIS \\
\hline 10.28 & 11.78 & L-KIS & $\begin{array}{l}\text { Complex } \\
\text { Production }\end{array}$ & SIS \\
\hline 5.80 & 8.25 & L-KIS & $\begin{array}{l}\text { Complex } \\
\text { Production }\end{array}$ & SIS \\
\hline 6.65 & 6.47 & Other & $\begin{array}{l}\text { Complex } \\
\text { Production }\end{array}$ & SIS \\
\hline 8.24 & 6.79 & H-KIS & $\begin{array}{l}\text { Complex } \\
\text { Production }\end{array}$ & SIS \\
\hline 7.93 & 3.11 & H-KIS & People Services & $\mathrm{AKP}$ \\
\hline 8.18 & 4.03 & H-KIS & People Services & $\mathrm{AKP}$ \\
\hline 9.23 & 2.30 & H-KIS & People Services & $\mathrm{AKP}$ \\
\hline 11.19 & 6.49 & H-KIS & People Services & AKP \\
\hline 7.33 & 3.96 & H-KIS & People Services & AKP \\
\hline 7.48 & 3.66 & H-KIS & People Services & $\mathrm{AKP}$ \\
\hline 10.35 & 6.17 & H-KIS & People Services & $\mathrm{AKP}$ \\
\hline 7.08 & 3.35 & L-KIS & People Services & AKP \\
\hline
\end{tabular}


7111 Performing Arts Companies

\begin{tabular}{ccclcc}
7.83 & 4.16 & H-KIS & People Services & PGS & NPS \\
7.48 & 3.64 & H-KIS & People Services & PGS & PS \\
9.81 & 2.62 & H-KIS & People Services & PGS & PS \\
11.21 & 4.66 & H-KIS & People Services & PGS & PS \\
7.15 & 2.92 & L-KIS & People Services & PGS & NPS \\
9.14 & 2.79 & L-KIS & People Services & PGS & NPS \\
10.37 & 3.07 & H-KIS & People Services & PGS & PS \\
8.38 & 2.31 & H-KIS & People Services & PGS & PS \\
9.62 & 3.68 & H-KIS & People Services & PGS & NPS \\
8.25 & 2.44 & H-KIS & People Services & PGS & PS \\
15.02 & 5.18 & H-KIS & People Services & PGS & NPS \\
9.48 & 3.17 & L-KIS & People Services & PGS & NPS \\
8.62 & 4.43 & H-KIS & People Services & PGS & PS \\
8.15 & 2.47 & H-KIS & People Services & PGS & PS \\
13.31 & 4.39 & H-KIS & People Services & PGS & PS \\
13.19 & 4.97 & H-KIS & People Services & PGS & NPS \\
9.72 & 2.95 & H-KIS & People Services & PGS & NPS \\
10.81 & 6.30 & H-KIS & People Services & PGS & PS \\
7.83 & 3.46 & L-KIS & People Services & PGS & NPS \\
14.75 & 4.83 & H-KIS & People Services & PGS & NPS \\
10.25 & 4.31 & H-KIS & People Services & PGS & PS \\
9.17 & 5.60 & H-KIS & People Services & PGS & PS \\
15.01 & 4.78 & H-KIS & People Services & PGS & PS \\
9.64 & 5.32 & H-KIS & People Services & PGS & PS \\
10.44 & 2.63 & H-KIS & People Services & PGS & PS \\
8.31 & 4.74 & H-KIS & People Services & PGS & PS \\
9.21 & 5.29 & H-KIS & People Services & PGS & PS \\
8.15 & 4.76 & H-KIS & People Services & PGS & PS \\
16.27 & 5.38 & H-KIS & People Services & PGS & NPS \\
\hline 1.48 & H-KIS & People Services & PGS & NPS
\end{tabular}




\begin{tabular}{|c|c|c|c|c|c|c|c|}
\hline 5331 & Lessors of Nonfinancial Intangible Assets (except Copyrighted Works) & 12.85 & 5.27 & L-KIS & People Services & SIS & PS \\
\hline 5221 & Depository Credit Intermediation & 7.20 & 2.81 & H-KIS & People Services & SIS & PS \\
\hline 5172 & Wireless Telecommunications Carriers (except Satellite) & 10.22 & 6.22 & H-KIS & People Services & SIS & PS \\
\hline 5151 & Radio and Television Broadcasting & 9.71 & 5.90 & H-KIS & People Services & SIS & PS \\
\hline 5259 & Other Investment Pools and Funds & 15.52 & 5.79 & H-KIS & People Services & SIS & PS \\
\hline 5191 & Internet Publishing and Broadcasting & 13.50 & 7.37 & H-KIS & People Services & SIS & PS \\
\hline 5222 & Nondepository Credit Intermediation & 8.88 & 3.46 & H-KIS & People Services & SIS & PS \\
\hline 5242 & Agencies, Brokerages, and Other Insurance Related Activities & 6.29 & 2.45 & H-KIS & People Services & SIS & PS \\
\hline 5241 & Insurance Carriers & 7.30 & 3.13 & H-KIS & People Services & SIS & PS \\
\hline 5232 & Securities and Commodity Exchanges & 30.29 & 11.83 & H-KIS & People Services & SIS & PS \\
\hline 5231 & Securities and Commodity Contracts Intermediation and Brokerage & 10.36 & 3.93 & H-KIS & People Services & SIS & PS \\
\hline 5223 & Activities Related to Credit Intermediation & 9.31 & 3.51 & H-KIS & People Services & SIS & PS \\
\hline 5239 & Other Financial Investment Activities & 9.46 & 3.70 & H-KIS & People Services & SIS & PS \\
\hline 5122 & Sound Recording Industries & 14.10 & 7.64 & H-KIS & People Services & SIS & SD \\
\hline 5211 & Monetary Authorities - Central Bank & 14.09 & 6.95 & H-KIS & People Services & SIS & PS \\
\hline
\end{tabular}

